\title{
Global atmospheric chemistry - which air matters
}

\author{
Michael J. Prather ${ }^{1}$, Xin Zhu ${ }^{1}$, Clare M. Flynn ${ }^{1}$, Sarah A. Strode ${ }^{2,3}$, Jose M. Rodriguez ${ }^{2}$, Stephen D. Steenrod ${ }^{2,3}$, \\ Junhua Liu ${ }^{2,3}$, Jean-Francois Lamarque ${ }^{4}$, Arlene M. Fiore ${ }^{5}$, Larry W. Horowitz ${ }^{6}$, Jingqiu Mao ${ }^{7}$, Lee T. Murray ${ }^{8}$, \\ Drew T. Shindell ${ }^{9}$, and Steven C. Wofsy ${ }^{10}$ \\ ${ }^{1}$ Department of Earth System Science, University of California, Irvine, CA 92697-3100, USA \\ ${ }^{2}$ NASA Goddard Space Flight Center, Greenbelt, MD, USA \\ ${ }^{3}$ Universities Space Research Association (USRA), GESTAR, Columbia, MD, USA \\ ${ }^{4}$ Atmospheric Chemistry, Observations and Modeling Laboratory, National Center for Atmospheric Research, \\ Boulder, CO 80301, USA \\ ${ }^{5}$ Department of Earth and Environmental Sciences and Lamont-Doherty Earth Observatory of Columbia University, \\ Palisades, NY, USA \\ ${ }^{6}$ Geophysical Fluid Dynamics Laboratory, National Oceanic and Atmospheric Administration, Princeton, NJ, USA \\ ${ }^{7}$ Geophysical Institute and Department of Chemistry, University of Alaska Fairbanks, Fairbanks, AK, USA \\ ${ }^{8}$ Department of Earth and Environmental Sciences, University of Rochester, Rochester, NY 14627-0221, USA \\ ${ }^{9}$ Nicholas School of the Environment, Duke University, Durham, NC, USA \\ ${ }^{10}$ School of Engineering and Applied Sciences, Harvard University, Cambridge, MA 02138, USA \\ Correspondence to: Michael J. Prather (mprather@uci.edu)
}

Received: 7 December 2016 - Discussion started: 16 January 2017

Revised: 25 May 2017 - Accepted: 3 July 2017 - Published: 27 July 2017

\begin{abstract}
An approach for analysis and modeling of global atmospheric chemistry is developed for application to measurements that provide a tropospheric climatology of those heterogeneously distributed, reactive species that control the loss of methane and the production and loss of ozone. We identify key species (e.g., $\mathrm{O}_{3}, \mathrm{NO}_{x}, \mathrm{HNO}_{3}, \mathrm{HNO}_{4}$, $\mathrm{C}_{2} \mathrm{H}_{3} \mathrm{NO}_{5}, \mathrm{H}_{2} \mathrm{O}, \mathrm{HOOH}, \mathrm{CH}_{3} \mathrm{OOH}, \mathrm{HCHO}, \mathrm{CO}, \mathrm{CH}_{4}$, $\mathrm{C}_{2} \mathrm{H}_{6}$, acetaldehyde, acetone) and presume that they can be measured simultaneously in air parcels on the scale of a few $\mathrm{km}$ horizontally and a few tenths of a $\mathrm{km}$ vertically. As a first step, six global models have prepared such climatologies sampled at the modeled resolution for August with emphasis on the vast central Pacific Ocean basin. Objectives of this paper are to identify and characterize differences in model-generated reactivities as well as species covariances that could readily be discriminated with an unbiased climatology. A primary tool is comparison of multidimensional probability densities of key species weighted by the mass of such parcels or frequency of occurrence as well as by the reactivity of the parcels with respect to methane and ozone. The reactivity-weighted probabilities tell us which parcels matter in this case, and this method shows skill in differen-
\end{abstract}

tiating among the models' chemistry. Testing $100 \mathrm{~km}$ scale models with $2 \mathrm{~km}$ measurements using these tools also addresses a core question about model resolution and whether fine-scale atmospheric structures matter to the overall ozone and methane budget. A new method enabling these six global chemistry-climate models to ingest an externally sourced climatology and then compute air parcel reactivity is demonstrated. Such an objective climatology containing these key species is anticipated from the NASA Atmospheric Tomography (ATom) aircraft mission (2015-2020), executing profiles over the Pacific and Atlantic Ocean basins. This modeling study addresses a core part of the design of ATom.

\section{Introduction}

To understand global atmospheric chemistry is to understand the chemical heterogeneity of air parcels across the vastness of the troposphere (e.g., Fishman et al., 1996; Ehhalt et al., 1997; Marenco et al., 1998; Jacob et al., 2003, 2010; Olson et al., 2004; Kunz et al., 2008; Nicely et al., 2016). These air parcels are ephemeral, being continually created, evolving, 
and mixed with others. Even the concept of discrete as opposed to a continuum of air parcels is a conceit based in part on our modeling of the atmosphere in quantized units such as gridded cells or $1 \mathrm{~s}$ averages. Yet, the concept of distinct air parcels remains useful for parsing in situ aircraft measurements and for the analysis presented here in which we ask which air is more important for the chemical evolution of global tropospheric pollution.

To understand the mix of chemicals in the atmosphere and where they come from is to recognize how humans have perturbed the common air we breathe. We seek knowledge of the photochemical evolution in each air parcel to understand the overall impact of this heterogeneity and to interpret human impact on past changes and predict future ones. The atmosphere's integration of this chemical reactivity over the ensemble of such heterogeneous air masses controls the evolution of air pollutants and reactive greenhouse gases, particularly methane and ozone. Hence, it allows us to evaluate the consequences of many atmospheric pollutants as regards global air quality and climate.

We have a tendency to simplify this heterogeneity as global, hemispheric, or even regional averages that can be represented with an average chemical composition. This holds true especially when diagnosing the sources and sinks of critical pollutants or when comparing models with atmospheric measurements. Yet, chemistry inherently involves quadratic reactions of two or more species and hence is nonlinear - viz. the chemistry integrated over a mix of parcels is not necessarily the same as that over the average of the mix (e.g., Chatfield and Delaney, 1990). We have progressed in modeling atmospheric chemistry over the past 4 decades from a few boxes (e.g., stratosphere and troposphere, northern and southern hemispheres) to high-resolution gridded models with many millions of cells. These models simulate myriads of air parcels that at times represent the observed atmospheric heterogeneity of species composition. For example, Fig. 1a presents a single-day snapshot of the column loss of methane as simulated by the UC Irvine chemistrytransport model (CTM) at a resolution of $1^{\circ}$ in latitude and longitude. Even column averages over $24 \mathrm{~h}$ show a filamentary structure with most of the tropospheric loss of methane occurring in sharp synoptic patterns. These chemical patterns have similarities with the atmospheric rivers of column water vapor (Newell et al., 1992; Dacre et al., 2015; Mundhenk et al., 2016) in terms of filamentary appearance and being dominated by the lower half of the troposphere. Nevertheless, the methane-loss filaments do not coincide with atmospheric rivers (Fig. 1a vs. 1b), indicating that chemical-specific heterogeneity other than tropical water vapor plays a role in these fine-scale structures (e.g., Ehhalt et al., 1997; Browell et al., 2003; Charlton-Perez et al., 2009).

This heterogeneity of species and chemical reactivity (e.g., methane loss) is clearly structured and not simply Gaussian. Its structure reflects the combined influence of meteorological transport and mixing as well as the patterns that differ- ent species are co-emitted and transformed around the globe. For example, large plumes from industrial regions or biomass burning when lofted into the free troposphere by deep convection or frontal systems will naturally be sheared into laminae, travel long distances, and appear ubiquitously (Newell et al., 1999; Stoller et al., 1999; Singh et al., 2000; Blake et al., 2003; Heald et al., 2003; Damoah et al., 2004; Hecobian et al., 2011; Wofsy et al., 2011). This shear or random strain in the atmosphere acts to maintain the pollution concentrated within the layer and preserves the sharp gradients relative to the neighboring atmosphere before they dissolve into the surrounding atmosphere, e.g., Prather and Jaffe (1990), Thuburn and Tan (1997), Esler (2003), and Pisso et al.2009). Characterizing chemical species in the atmosphere as having mean abundances, or even mean vertical profiles, with a standard deviation to represent the observed variability, does not really describe how these models generate heterogeneity and how the different species co-vary. Assuredly, the atmosphere has more processes and structures than are in our current, high-resolution models as seen in Fig. 1, but the extent to which these models represent the key processes shaping the observed patterns is understudied.

Characterizing atmospheric measurements of this chemical heterogeneity specifically for testing models is problematic. Simple direct comparisons of atmospheric rivers, pollution or biomass burning plumes, and other structures in the troposphere or stratosphere are difficult, even with models using the historical meteorology and chemical emissions, because of slight phase errors in the location of large-scale gradients or laminae (e.g., Reid et al., 1998; Manney et al., 1998; Wild et al., 2003; Kiley et al., 2003; Allen et al., 2004; Schoeberl et al., 2007; Elguindi et al., 2010). The other type of chemistry models, the chemistry-climate models (CCMs), are our means of understanding future air pollution (Prather et al., 2003; Mickley et al., 2004; Jacob and Winner, 2009; Fiore et al., 2012; Barnes and Fiore, 2013; Turner et al., 2013; Fang et al., 2013; Schnell et al., 2015), but CCMs describe the chemical climate and not the hindcast of specific chemical measurements. Most large CCM groups have parallel CTM versions, but these forced-meteorology versions will likely have different clouds, convection, and transport, changing the chemical climatology. Aircraft campaigns often use photochemical box models to provide an observationally constrained check on reactive species (Olson et al., 2004, 2012; Apel et al., 2012; Stone et al., 2012), and more recently these have extended the box model as a transfer standard across CCMs-CTMs (Nicely et al., 2017) that can integrate reactive chemistry over $24 \mathrm{~h}$. The problem remains that the $24 \mathrm{~h}$ integration requires a global model's diagnostics for the diurnal cycle of cloud cover and ozone-aerosol influence on photolysis.

We describe a new approach for developing chemical climatologies from atmospheric chemistry measurements and for using the major global 3-D CTMs-CCMs as box-models to integrate the $24 \mathrm{~h}$ rates for important species like methane 
and ozone. Our goal is to provide climatologies that can point to specific patterns of the key chemical species whose initial values control the chemical evolution of the air parcels. Knowing the correct multi-species patterns, and how different models succeed or fail in reproducing them, will give developers the largest leverage in improving the chemical and physical processes in the models. A critical issue in preparing such a chemical climatology is representativeness, i.e., just how well do the observations represent the region in which they were made and how well should the models match the space-time frequency of the observations. There is growing literature on the issues of representativeness of atmospheric measurements (Nappo et al., 1982; Crawford et al., 2003; Hsu et al., 2004; Ramsey and Hewitt, 2005; Larsen et al., 2014; Eckstein et al., 2017) including defining the chemical patterns through cluster analysis (Köppe et al., 2009).

There have been many aircraft missions designed to provide a wealth of in situ, high-resolution atmospheric chemistry data, including some with a nearly complete package of key species needed to calculate reactivities (Jacob et al., 2003, 2017; Engel et al., 2006; Pan et al., 2017). Unfortunately, many of these produced a biased, non-climatological sampling, for example, by chasing pollution plumes (Hsu et al., 2004) or by measuring only in clear skies (Nicely et al., 2016). The Pacific Exploratory Missions, PEM-Tropics and PEM-West, were notable in providing a mostly unbiased, exploratory sampling of specific regions in the remote $\mathrm{Pa}$ cific with a full chemical payload measuring most of the key species (Hoell et al., 1996, 1999; Raper et al., 2001; Davis et al., 2003). The MOZAIC-IAGOS program uses in-service aircraft and has provided a unique multi-year, objective climatology of some key species $\left(\mathrm{O}_{3}, \mathrm{CO}, \mathrm{H}_{2} \mathrm{O}\right)$ but only along major flight routes at cruise altitudes $(8-12 \mathrm{~km})$ and at profiles above airports (Marenco et al., 1998; Thouret et al., 1998; Kunz et al., 2008; Elguindi et al., 2010; Logan et al., 2012; Gaudel et al., 2015).

We examine below some aspects of making objective climatologies of chemical observations, in particular the representativeness of atmospheric transects over the remote ocean basins. Our approach was designed specifically as part of the current NASA Atmospheric Tomography (ATom) aircraft mission in which the DC- 8 is instrumented to make highfrequency in situ measurements of the most important reactive species and flies down the middle of the Pacific and Atlantic oceans, profiling as frequently as possible. The resulting climatology represents the heterogeneity of the atmosphere, including the covariance of key reactive species.

This approach is tested here using six CTMs-CCMs described in Table 1. It allows us to identify models that look alike in reactivity statistics and those that are distinctly different. We have seen large uniform anomalies in a specific species as well as different patterns or locations of the most reactive parcels. For example, we list the models' average reactivities for the tropical Pacific and the globe in Table 1c. The tropical Pacific average P-O3 is similar across models and is about $1 / 2$ that of the global average, which is dominated polluted, near-surface parcels over land. The L-O3 is typically the same for the Pacific and the globe; and the LCH4 is greater over the Pacific than over the globe. Model $\mathrm{D}$ stands out in reversing or exaggerating these typical Pacific vs. globe differences, indicating very different locations for the reactivity. We use these models to demonstrate the methodology and the ability to discriminate among them with ATom-like measurements. Model versions used here should be considered snapshots in the development cycle. No model tuning or development occurred as part of this work, except to correct where quantities were missed or misdiagnosed. These diagnostics need to be revisited for the model versions used in upcoming assessments (e.g., Lamarque et al., 2013; Collins et al., 2016)

Typically, the probability of occurrence of a species' abundance is weighted by the air mass of the parcel, but, if we are interested in the chemical reactivity, then the parcel should be weighted by the chemical rates in the parcel (e.g., moles per day). Such weighting is an obvious choice in that it tells us which air parcels matter for chemical budgets, including, for example, whether infrequently observed pollution plumes are responsible for a large fraction of ozone production.

In Sect. 2 we define our use of reactivity in this paper (i.e., the production and loss of ozone, the loss of methane) and identify about a dozen key chemical species and other variables that once initialized determine the chemical evolution of an air parcel. In Sect. 3 we show how the CTMsCCMs can be altered slightly to calculate the reactivity of air parcels using the native grid cells of the model and a prescribed initialization of the key chemical species. This approach allows the CTMs-CCMs to be run using either model data or observations, or a mixture of both. In Sect. 4 we derive multi-dimension probability distributions for these key variables over a suitable latitude-longitude-pressure domain using grid-cell values from several CTMs-CCMs. Tables of simplified statistics describing these probability distributions are presented and discussed in the Supplement to this paper. The full distributions and simple statistics clearly show the basic differences in chemical heterogeneity and reactivity across the six models. We conclude in Sect. 5 with a summary of the model comparisons and what is learned from the new diagnostics. We also discuss the ongoing NASA ATom mission (2015-2020), which will provide the air parcel measurements of key species to initialize the models' calculation of reactivity in each parcel and thus provide an observed climatology of the chemical reactivity of the troposphere. This approach moves us towards an understanding of which species exert the largest influence on the atmosphere and thus which are most crucial for us to establish a global climatology. 
Table 1. Chemistry-Transport and Chemistry-Climate models used in this work.

\begin{tabular}{llllll}
\hline \multicolumn{2}{l}{ (a) Participating models } & & & & \\
\hline Model & Type & Driving meteorology & Year & Model grid & Effective resol. 500 hPa \\
\hline CAM4-Chem & CCM & SSTs & $2000 \mathrm{~s}$ & $0.47^{\circ} \times 0.625^{\circ} \times 52 \mathrm{~L}$ & $0.47^{\circ} \times 0.625^{\circ} \times 38 \mathrm{hPa}$ \\
GEOS-Chem & CTM & GEOS5-FP & 2013 & $2^{\circ} \times 2.5^{\circ} \times 72 \mathrm{~L}$ & $2^{\circ} \times 2.5^{\circ} \times 38 \mathrm{hPa}$ \\
GFDL-AM3 & CCM & NCEP (nudged) & 2013 & $\mathrm{C} 180 \mathrm{~L} 48$ & $0.5^{\circ} \times 0.5^{\circ} \times 71 \mathrm{hPa}$ \\
GISS-E2 & CCM & Daily SSTs prescribed, winds nudged to MERRA & 2013 & $2^{\circ} \times 2.5^{\circ} \times 40 \mathrm{~L}$ & $2^{\circ} \times 2.5^{\circ} \times 50 \mathrm{hPa}$ \\
GMI-CTM & CTM & MERRA & 2001 & $1^{\circ} \times 1.25^{\circ} \times 72 \mathrm{~L}$ & $1^{\circ} \times 1.25^{\circ} \times 38 \mathrm{hPa}$ \\
UCI-CTM & CTM & ECMWF IFS Cy38r1 & 2005 & T159N80L60 & $1.1^{\circ} \times 1.1^{\circ} \times 38 \mathrm{hPa}$ \\
\hline
\end{tabular}

(b) Points of contact and model url's

\begin{tabular}{llll}
\hline Model & POC & Email & Model url \\
\hline CAM4-Chem & Jean-Francois Lamarque & lamar@ucar.edu & http://www.cesm.ucar.edu/models/current.html \\
GEOS-Chem & Lee Murray & lee.murray@ rochester.edu & http://wiki.seas.harvard.edu/ \\
GFDL-AM3 & Arlene Fiore & amfiore@ldeo.columbia.edu & https://www.gfdl.noaa.gov/am3-model/ \\
GISS-E2 & Lee Murray & lee.murray@rochester.edu & http://www.giss.nasa.gov/tools/modelE/ \\
GMI-CTM & Sarah Strode & sarah.a.strode@ nasa.gov & http://gmi.gsfc.nasa.gov \\
UCI-CTM & Michael Prather & mprather@uci.edu & ftp://halo.ess.uci.edu/public/xzhu/qcode_72c \\
\hline
\end{tabular}

(c) Model average reactivities $\left(\mathrm{ppb}_{\mathrm{day}}{ }^{-1}\right.$ ) for P-O3, L-O3, and L-CH4

\begin{tabular}{|c|c|c|c|c|c|c|c|}
\hline \multirow[t]{2}{*}{ Model } & \multirow[t]{2}{*}{ Code } & \multicolumn{2}{|c|}{ P-O3 } & \multicolumn{2}{|c|}{ L-O3 } & \multicolumn{2}{|c|}{ L-CH4 } \\
\hline & & Tr. Pac. & Global & Tr. Pac. & Global & Tr. Pac. & Global \\
\hline CAM4-Chem & $\mathrm{A}$ & 0.979 & 2.070 & 1.963 & 1.802 & 1.017 & 0.745 \\
\hline GEOS-Chem & B & 0.791 & 2.252 & 1.616 & 1.837 & 0.765 & 0.738 \\
\hline GFDL-AM3 & $\mathrm{C}$ & 0.860 & 2.036 & 1.550 & 1.535 & 0.726 & 0.599 \\
\hline GISS-E2 & $\mathrm{D}$ & 1.092 & 3.715 & 2.589 & 3.409 & 0.453 & 0.693 \\
\hline GMI-CTM & $\mathrm{E}$ & 0.778 & 1.513 & 1.834 & 1.690 & 0.848 & 0.674 \\
\hline UCI-CTM & $\mathrm{F}$ & 1.088 & 2.100 & 1.788 & 1.990 & 0.854 & 0.702 \\
\hline
\end{tabular}

All results are mass-weighted by tropospheric parcels up to $200 \mathrm{hPa}$ from the model C-runs for 16 August.

\begin{tabular}{lll}
\hline (d) Model references & \\
\hline Model & Code & Relevant references \\
\hline CAM4-Chem & A & Lamarque et al. (2012); Tilmes et al. (2016) \\
GEOS-Chem & B & Bey et al. (2001); Eastham et al. (2014) \\
GFDL-AM3 & C & Donner et al. (2011); Naik et al. (2013a); Li et al. (2016) \\
GISS-E2 & D & Schmidt et al. (2014); Shindell et al. (2013) \\
GMI-CTM & E & Strahan et al. (2007); Duncan et al. (2007) \\
UCI-CTM & F & Holmes et al. (2013, 2014); Prather (2015); Sovde et al. (2012) \\
\hline
\end{tabular}

\section{Key chemical species for tropospheric reactivity}

The reactivity of an air parcel is defined here as a daily average of the rates affecting critical species, in this case, ozone $\left(\mathrm{O}_{3}\right)$; a greenhouse gas and air quality threat; and methane $\left(\mathrm{CH}_{4}\right)$, the second most important emitted greenhouse gas after $\mathrm{CO}_{2}$. Methane is emitted mostly through human activities but also naturally; and it is lost primarily (>80\%) through reaction with the hydroxyl radical $(\mathrm{OH})$ in the troposphere (Reaction 1). Other atmospheric losses in decreasing order of magnitude and certainty are reaction with stratospheric $\mathrm{OH}$, surface uptake by biota, and reaction with $\mathrm{Cl}$ atoms (Prather et al., 2012; Ciais et al., 2013).

$\mathrm{CH}_{4}+\mathrm{OH} \rightarrow \mathrm{CH}_{3}+\mathrm{H}_{2} \mathrm{O}$

The $\mathrm{CH}_{4}$ abundance varies little throughout the troposphere $(\sim 10 \%)$, and the destruction of $\mathrm{CH}_{4}$ occurs with a mean loss frequency of $\sim 0.1 \mathrm{yr}^{-1}$ (see Fig. 1a). Here we focus on calculating the tropospheric loss of $\mathrm{CH}_{4}$ by $\mathrm{OH}$ over $24 \mathrm{~h}$ (Reaction 1, designated L-CH4) in units of ppb (nanomoles mol$\mathrm{air}^{-1}$ ) per day. L-CH4 is highly variable across parcels, and 

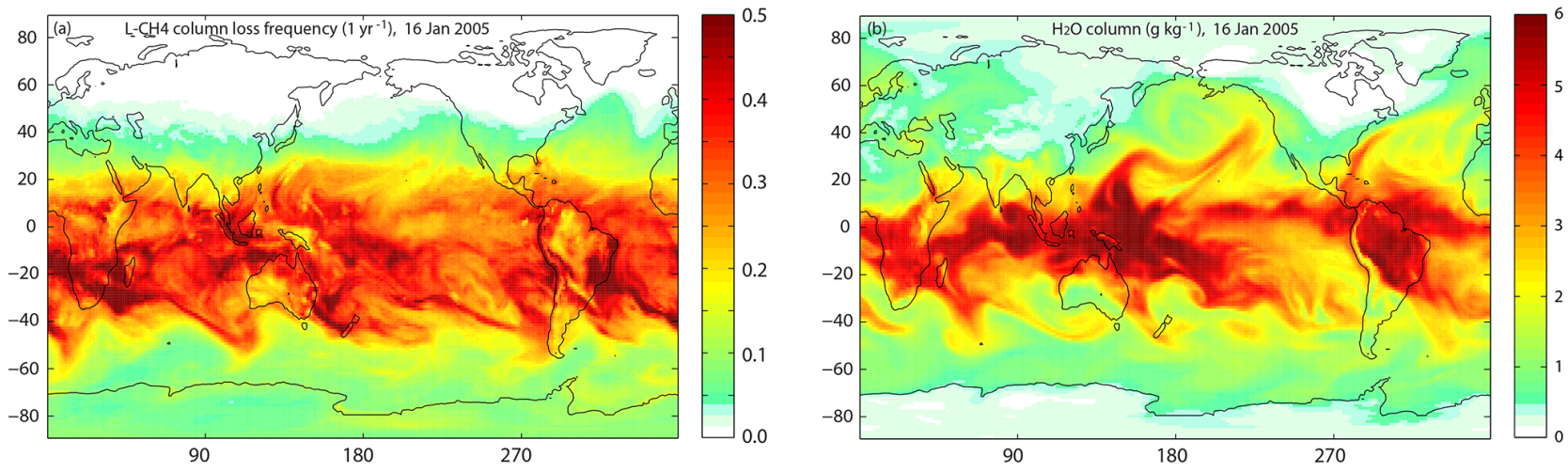

Figure 1. (a) Column tropospheric loss frequency $\left(1 \mathrm{yr}^{-1}\right)$ for $\mathrm{CH}_{4}$ and (b) column average $\mathrm{H}_{2} \mathrm{O}$ abundance $\left(\mathrm{g}-\mathrm{H}_{2} \mathrm{O}\right.$ kg-air $\left.{ }^{-1}\right)$ taken from a 1-day integration (16 January 2005) using the University of California, Irvine (UCI) chemistry-transport model (CTM) run at T319N80L57 resolution $\left(\sim 1^{\circ}\right.$ horizontal) using forecast meteorology from the European Centre for Medium-Range Weather Forecasts, see Sovde et al. (2012). As expected, the northern winter shows very little $\mathrm{CH}_{4}$ loss above $40^{\circ} \mathrm{N}$.

the integral of L-CH4 determines the atmospheric lifetime of $\mathrm{CH}_{4}$ and the buildup of its emissions in the atmosphere.

Tropospheric $\mathrm{O}_{3}$ has stratospheric sources and surface sinks, which average to about $0.2-0.3 \mathrm{ppb}$ per day, and much larger in situ photochemical production and losses that average about 1.1-1.5 ppb per day (Stevenson et al., 2006, 2013; Young et al., 2013; Hardacre et al., 2015). The $\mathrm{O}_{3}$ abundance varies greatly throughout the troposphere, by a factor of 10 or more, and its mean residence time is about a month (Stevenson et al., 2006; Wu et al., 2007; Hsu and Prather, 2009). $\mathrm{O}_{3}$ is an intermediate source of atomic $\mathrm{O}$ in many tropospheric reactions, and its net production and loss is determined in the long term by the breaking and reforming of the $\mathrm{O}-\mathrm{O}$ bond originating with molecular oxygen. Chemical reactions are traditionally grouped into production ( $\mathrm{P}-\mathrm{O} 3, \mathrm{ppb}^{\mathrm{day}}{ }^{-1}$ ),

$\mathrm{HO}_{2}+\mathrm{NO} \rightarrow \mathrm{NO}_{2}+\mathrm{OH}$,

$\mathrm{RO}_{2}+\mathrm{NO} \rightarrow \mathrm{NO}_{2}+\mathrm{RO}$,

where $\mathrm{NO}_{2}+h v \rightarrow \mathrm{NO}+\mathrm{O}$ and $\mathrm{O}+\mathrm{O}_{2} \rightarrow \mathrm{O}_{3}$,

$\mathrm{O}_{2}+h v \rightarrow \mathrm{O}+\mathrm{O}(\times 2)$

and loss (L-O3, ppb day $\left.{ }^{-1}\right)$.

$\mathrm{O}_{3}+\mathrm{OH} \rightarrow \mathrm{O}_{2}+\mathrm{HO}_{2}$,

$\mathrm{O}_{3}+\mathrm{HO}_{2} \rightarrow \mathrm{HO}+\mathrm{O}_{2}+\mathrm{O}_{2}$,

$\mathrm{O}\left({ }^{1} D\right)+\mathrm{H}_{2} \mathrm{O} \rightarrow \mathrm{OH}+\mathrm{OH}$,

where $\mathrm{O}_{3}+h v \rightarrow \mathrm{O}\left({ }^{1} D\right)+\mathrm{O}_{2}$.

In the troposphere, Reaction (2d) is important only in the tropics above $12 \mathrm{~km}$ (Prather, 2009). The true P minus L of $\mathrm{O}_{3}$ includes a large number of other reactions, particularly involving oxides of nitrogen and hydrocarbons; but throughout the remote troposphere (i.e., away from fresh pollution sources), Reactions (2) minus Reactions (3) accurately approximate the true $\mathrm{P}-\mathrm{L}$ that the models calculate using the full set of reactions. One reason for separating $\mathrm{P}$ and $\mathrm{L}$ in this way is to think of $\mathrm{P}$ as independent of $\mathrm{O}_{3}$ and $\mathrm{L}$ as being linearly proportional. Unfortunately, while the P Reactions (2) have no obvious $\mathrm{O}_{3}$ terms, both these reactions and the $\mathrm{OH}$ and $\mathrm{HO}_{2}$ abundances in Reactions (3) depend indirectly on $\mathrm{O}_{3}$; and thus with a true linearization of $\mathrm{P}-\mathrm{L}$, the lifetime of $\mathrm{O}_{3}$ is much shorter than inferred from $\mathrm{L}$ (Prather and Holmes, 2013). A similar chemical feedback with opposite sign occurs for $\mathrm{CH}_{4}$ whereby the lifetime of a $\mathrm{CH}_{4}$ addition is longer than inferred from the linear relationship of Reaction (1) (Prather, 1996). We retain these definitions of $\mathrm{P}-\mathrm{O} 3, \mathrm{~L}-\mathrm{O} 3$, and L-CH4 because they still represent the reactivity in remote regions and the reaction rates, rather than a linearization, are straightforward CTM-CCM diagnostics.

We define the reactivity of an air parcel (Reactions 1-3) in terms of $24 \mathrm{~h}$ average rates and hence the units of ppb per day. Reactivity defined here requires sunlight; nighttime sources of $\mathrm{OH}$ from alkenes and isoprene via ozonolysis or nitrate radicals (Paulson and Orlando, 1996) are important primarily in continental air over emission sources. This calculation integrates over the diurnal cycle of photolysis rates driven by changing solar zenith angle, clouds, $\mathrm{O}_{3}$, and aerosol profiles, all of which are simulated in CTM-CCMs.

What key constituents are needed for modeling reactivity? Models simulate many tens to hundreds of chemical species. While many are important for calculating the instantaneous reaction rates, e.g., $\mathrm{O}\left({ }^{1} D\right)$, they are not the key species. Key is defined here as a constituent whose initial value significantly affects the $24 \mathrm{~h}$ reactivity, whereas other species can be initialized to any reasonable value and not affect it. For example, $\mathrm{OH}$ and $\mathrm{HO}_{2}$ are radical $\mathrm{HO}_{x}$ species whose abundances directly determine the rates of Reactions (1)(3). Nevertheless, these are not key species as their abundances can be initialized to zero and are rapidly reset in seconds to a temporary steady state with first sunlight or changing clouds through Reactions (3c, d) among others (Rohrer 
and Berresheim, 2006). This argument applies to similar radical species such as $\mathrm{CH}_{3} \mathrm{OO}$, but not to $\mathrm{HO}_{x}$ sources like $\mathrm{CH}_{3} \mathrm{OOH}$ and $\mathrm{HOOH}$ whose initial values will control the abundance of $\mathrm{OH}$ and the reactivities over the day.

A similar situation applies to $\mathrm{NO}$ and $\mathrm{NO}_{2}$ (collectively designated $\mathrm{NO}_{x}$ ), whereby total $\mathrm{NO}_{x}$ changes over the day as it is exchanged with higher oxides of nitrogen, but the fraction of $\mathrm{NO}_{x}$ in the form of $\mathrm{NO}$ is determined rapidly in sunlight by Reactions (2a), (2b), (2c), and (4).

$\mathrm{NO}+\mathrm{O}_{3} \rightarrow \mathrm{NO}_{2}+\mathrm{O}_{2}$

In the dark, $\mathrm{NO}_{x}$ is almost entirely $\mathrm{NO}_{2}$, and it is critical to initialize $\mathrm{NO}_{x}$, but not $\mathrm{NO}$ and $\mathrm{NO}_{2}$ separately.

Based on sensitivity tests with the UCI-CTM, our list of 18 key species includes $\mathrm{O}_{3}, \mathrm{NO}_{x}, \mathrm{HNO}_{3}, \mathrm{HNO}_{4}, \mathrm{PAN}$ $\left(\mathrm{C}_{2} \mathrm{H}_{3} \mathrm{NO}_{5}=\right.$ peroxyacetyl nitrate), $\mathrm{RNO}_{3}\left(\mathrm{CH}_{3} \mathrm{NO}_{3}\right.$ and all alkyl nitrates), $\mathrm{HOOH}, \mathrm{ROOH}\left(\mathrm{CH}_{3} \mathrm{OOH}\right.$ and smaller contribution from $\mathrm{C}_{2} \mathrm{H}_{5} \mathrm{OOH}$ ), $\mathrm{HCHO}, \mathrm{CH}_{3} \mathrm{CHO}$ (acetaldehyde), $\mathrm{C}_{3} \mathrm{H}_{6} \mathrm{O}$ (acetone), $\mathrm{CO}, \mathrm{CH}_{4}, \mathrm{C}_{2} \mathrm{H}_{6}$, alkanes (all $\mathrm{C}_{3} \mathrm{H}_{8}$ and higher), alkenes (all $\mathrm{C}_{2} \mathrm{H}_{4}$ and higher), aromatics (benzene + toluene + xylene), and $\mathrm{C}_{5} \mathrm{H}_{8}$ (isoprene + terpenes).

We also add $p(\mathrm{hPa}), T(\mathrm{~K}), q\left(\mathrm{~g}-\mathrm{H}_{2} \mathrm{O}\right.$ kg-air $\left.^{-1}\right)$, and latitude and longitude to make up the 23 key variables in each air parcel. Some collectives like alkanes may be treated as multiple, separate species in some models or may be lumped according to their reaction rates. The abovementioned list tends to be inclusive because, for much of the troposphere, a smaller list can apply. For some species (e.g., $\mathrm{C}_{5} \mathrm{H}_{8}$ ), their role is key only if they are present in large enough abundances, but even when sampling across the Pacific Ocean basin one may find plumes with recent biospheric sources.

This simplification of the chemical system fails in regions of intense emissions of short-lived species or in highly polluted environments such as urban, industrial, or open fires. After pollution plumes have been separated from sources and aged a few days, our key variables should define the reactivity. Such conditions apply to most of the troposphere, particularly the air over the vast Pacific and Atlantic Ocean basins. With aged pollution plumes, we expect that some key species (e.g., alkenes, isoprene, aromatics, and higher alkanes) will drop off the list because their abundances in much of the remote mid-ocean regions will have fallen below the relevance threshold.

\section{Modeling the reactivity of air parcels}

Why use the global models instead of single-box models to calculate reactivity statistics? There are several reasons. For one, these CTMs-CCMs simulate the full meteorology including cloud cover and its variation over large regions, which is a critical component of reactivity. Second, they usually include self-evaluated ozone and aerosol profiles also needed for the photolysis rates. Third, these models automatically simulate the diurnal cycle in radiation at all seasons, latitudes, and longitudes. And fourth, most importantly, these models have built-in chemistry modules that already calculate reactivities, and they are the ones we rely on for climate and air quality assessments. The goal here is to test their simulated chemical heterogeneity. While a box model could be designed (using 3-D meteorology) to address the first three needs (e.g., Nicely et al., 2016), it cannot address the last. More simply, all the necessary Earth system components are already built in to the CTMs-CCMs, and our approach of testing the modeled climatologies includes that of testing the Earth system components (e.g., emissions, transport, chemistry, scavenging, air-sea exchange, and land-surface interactions).

In a standard CTM or CCM simulation (defined here as a C-run), we calculate the reactivity at a given grid cell, but not that of a parcel. Air parcels move, change location, and mix with neighboring parcels: i.e., there is no way to track quantitatively what might be considered the original parcel. Effectively, we keep integrating the rates in that grid cell as different parcels travel through it and are mixed within it. Let us take a large enough domain of grid cells (e.g., tropical $\mathrm{Pa}$ cific, $150-210^{\circ} \mathrm{E}$, from surface to $200 \mathrm{hPa}$ ) and calculate the statistical distribution of reactivities of all those grid cells. We take these statistics to be equivalent to those we would get from integrating the reactivity over isolated air parcels with the same initialization. Of course the latter is only a thought experiment since the parcels do not remain isolated. In C-runs new air parcels are entering the domain and others are exiting. In a single cell we can start with a polluted lamina and end with clean air convected from the marine boundary layer, but much of the polluted lamina remains in the larger domain. As long as the domain retains a statistical mix of the key chemical species similar to the initialization, then the reactivity statistics of the C-run should represent the hypothetical reactivity of those initialized parcels.

How can we design a calculation using the CTMs-CCMs that allows us to initialize a subset of grid cells with observed air parcels and then calculate a reactivity for those parcels? The goal here is to be able to use the NASA ATom aircraft mission (2015-2020), which was designed to measure those 23 key variables in air parcels profiling from near-surface to $12 \mathrm{~km}$ altitude, flying ascents and descents down the middle of the Pacific and Atlantic Ocean basins. Thus ATom data will not fill the global 3-D model grid, and thus many cells will be initialized with the model's original chemistry values. The critical design requirement is that we let the model integrate for $24 \mathrm{~h}$ as it normally does in a way that the chemistry in each grid cell depends minimally on any of the grid cells around it.

We thus propose an A-run mode (named after the ATom mission) for the CTMs-CCMs in which individual parcel reactivities can be calculated, albeit with some simplifying approximations. Consistent with our definition of reactivity, we consider only ATom parcels that are tropospheric. The A-runs disable processes that connect and mix air parcels. 
First we drop all calls to the tracer transport sections (advection, convection, diffusion, boundary layer mixing). Second, we must cut all emissions, including lightning and aircraft $\mathrm{NO}_{x}$, because without transport the emissions would build up unrealistically in the source cells. Third, all tracer scavenging modules must be turned off because in many models the scavenging depends on the vertical distribution of the species.

In this A-mode, the remaining connection of the reactivity calculation with neighboring grid cells is through the photolysis rates, which require profiles of clouds, aerosol layers, and ozone. It is impossible to prescribe all these data over the diurnal cycle for each parcel from observations, and thus we must rely on the CTM-CCM to generate a suitably realistic, diurnal, regional, seasonal climatology for these and hence the photolysis rates. To better average the reactivity over synoptic variations in clouds, we expect to repeat the same initialization of the A-runs for a range of days over a month containing the observations.

Each ATom parcel (2-8 km along the flight path) will be assigned a unique model grid cell to best match the observation: latitude and pressure grids containing the measurement, and longitude chosen as close as possible but maintaining a unique cell for each parcel. ATom parcels in adjacent grid cells may represent air masses separated by a few km instead of the grid-cell size of order $100 \mathrm{~km}$. A high density of ATom parcels in a region will be placed in the correct latitude and pressure cells but may be strung out in longitude cells. The parcel will use the mole fraction of key species, water vapor $(q)$ and temperature $(T)$ as measured, but will adopt the mean pressure of the grid cell. The model may need to maintain separate storage for the hourly $T$ and $q$ used in the CCM dynamics because it is important to maintain the clouds as they would be done in the C-run, and thus the main-code values of $T$ and $q$ cannot be overwritten with ATom values. The A-run treatment of stratospheric $\mathrm{O}_{3}$ (i.e., fixed) is unlikely to be identical to the C-run, but it does not appear to drive major changes in the average photolysis rates over a region (see below).

In defining the A-runs, we have thus created some biases in the reactivities relative to the $\mathrm{C}$-runs. Examination of the $\mathrm{NO}_{x}$ and $\mathrm{HO}_{x}$ budgets of parallel A- and C-runs shows two obvious differences. The A-runs lack emissions. Over the remote ocean basins, the most important emission is $\mathrm{NO}_{x}$ (lightning, shipping, aviation). Thus A-runs show a $24 \mathrm{~h}$ decline in $\mathrm{NO}_{x}$ abundances compared with the C-runs, resulting in generally lower $\mathrm{P}-\mathrm{O} 3$. The A-runs also lack scavenging and thus accumulate more $\mathrm{HNO}_{3}$ and $\mathrm{HO}_{x}$ precursors like $\mathrm{HOOH}$, affecting L-CH4. No other simple objective approach has been found, and we must accept and document these biases in the A-runs.

An examination of how the A- and C-runs differ is shown in Fig. 2 using the UCI-CTM's 1-D probability distributions of six key species $\left(\mathrm{NO}_{x}, \mathrm{HNO}_{3}, \mathrm{HNO}_{4}, \mathrm{PAN}, \mathrm{HCHO}\right.$, $\mathrm{HOOH})$ for the central tropical Pacific. The initial distribu- tion for both runs $\left(12 \mathrm{~h}\right.$ local solar time at $180^{\circ} \mathrm{E}$, black solid) can be compared with that for $24 \mathrm{~h}$ later $(36 \mathrm{~h})$ for the C- (black dashed) and A-runs (cyan squares, only for four species). The number of moles at the beginning and end of the $24 \mathrm{~h}$ in the C-run (see legend) is a measure of the daily changes in the air parcels entering and leaving the domain. It varies from 0 to $4 \%$, which is well within the expected representativeness of a given day. With the A-run, however, we see large systematic shifts due to the lack of emissions $\left(\mathrm{NO}_{x}\right)$ and scavenging $\left(\mathrm{HNO}_{3}, \mathrm{HOOH}\right)$. For $\mathrm{HNO}_{3}$ the content increases overall by $9 \%$, with the high-end (>100 ppt) distribution not changing, but the low-end $(<20 \mathrm{ppt})$ air gains $\mathrm{HNO}_{3}$, increasing the middle section (20-100 ppt). This is logical because the low- $\mathrm{HNO}_{3}$ regions have the most scavenging. This change in distribution over the $24 \mathrm{~h}$ integration of the A-runs is unlikely to change the reactivities as the release of $\mathrm{NO}_{x}$ from $\mathrm{HNO}_{3}$ will be more important in the high- $\mathrm{HNO}_{3}$ regions. For $\mathrm{NO}_{x}$ the content decreases overall by $18 \%$, with most air parcels (4-100 ppt) becoming less frequent and an increase in frequency only for parcels with very low $\mathrm{NO}_{x},<4$ ppt. The $1-\mathrm{D}$ distribution of $\mathrm{HCHO}$ shifts lightly but with little overall change in content. The lack of scavenging is even more important for $\mathrm{HOOH}$ with an overall increase of $41 \%$ and a dramatic shift in the distribution: decreases in $0.3-1.0 \mathrm{ppb}$ appear as very large increases from 1.0 to $2.5 \mathrm{ppb}$. The implications for using the A-run bias in computing the reactivities are examined with all six models below.

An important assumption in using key species to initialize the reactivity simulations is that the diurnal cycle is not critical, and ATom measurements can be used without trying to make corrections for the time of measurement. In running these global models, it is not practical to initialize parcels at other than a standard day (i.e., beginning at 00:00 UT). For some species like HCHO, the daytime loss frequency in the tropics is about $1 / 2 \mathrm{~h}^{-1}$ (see for example loss photolysis rates for various oxygenated hydrocarbons in Prather, 2015), and thus one might expect it to vary greatly over the sunlight day or with cloud variations. The diurnal change in 1-D distributions of the 6 key species is also shown in Fig. 2 for the $\mathrm{C}$-runs at $18 \mathrm{~h}$ (local solar time, red dashed), $24 \mathrm{~h}$ (dark blue dashed), and $30 \mathrm{~h}$ (green dashed). The C-runs are in approximate steady-state over the tropical Pacific domain as seen by comparing $12 \mathrm{~h}$ with $36 \mathrm{~h}$, and thus these sunset-midnightsunrise times show the daily variations. The diurnal cycle does produce visible shifts in the 1-D distributions, particularly at the end of the night $(30 \mathrm{~h})$. The shifts in $\mathrm{HCHO}$ are small considering its high loss frequency, primarily because both sources and sinks respond similarly to photolysis rates. The seemingly longer-lived $\mathrm{HOOH}$ shows larger shifts because production occurs in sunlight but scavenging occurs day and night. PAN and $\mathrm{HNO}_{4}$ show small diurnal cycles at the high abundance end of their distributions where they can be important $\mathrm{NO}_{x}$ sources, and initialization errors caused 
by the diurnal cycle at the low abundances will have smaller impacts on reactivity.

A test of A- vs. C-runs for all six CTMs-CCMs is shown Fig. 3. All models were spun up for a year and stopped at 00:00 UT on 16 August, with the chemical abundances at this time being used to initialize each model's own C- and A-runs. In this case all species in the model were initialized and not just the 18 key species. Each model ran their own chemistry and meteorology intended to simulate a specific historical year or a typical climate year. All were intended to be typical of the last decade. The models were then run for $24 \mathrm{~h}$ and the rates and reactivities diagnosed for both C-runs and A-runs. All models have different resolutions, ranging from 0.5 to $2^{\circ}$. All model statistics (key variables, reactivities, plus $24 \mathrm{~h}$ average photolysis rates) were stored globally. This analysis examines a north-south transect flight over the Pacific Ocean basin as in the NASA ATom flights but greatly expands the region to include more grid cells: six domains with latitude boundaries at $60-40^{\circ} \mathrm{S}, 40-20^{\circ} \mathrm{S}, 20^{\circ} \mathrm{S}-0^{\circ}, 0$ $20^{\circ} \mathrm{N}, 20-40^{\circ} \mathrm{N}$, and $40-60^{\circ} \mathrm{N}$ (each region is color keyed in Fig. 3); longitude, in a single broad domain, $150-210^{\circ} \mathrm{E}$. Vertical profiles $(200-1000 \mathrm{hPa})$ on the models' native grid are shown for the six domains as different colors. The standard C-runs with all transport and emissions included are solid lines, while the ATom-like A-runs are dashed.

For L-CH4, the only general agreement is the lesser importance of parcels at altitudes above $500 \mathrm{hPa}$. For this August test, most models find that the $20-40^{\circ} \mathrm{N}$ dominates (note that plots are ppb day ${ }^{-1}$ and not area weighted), and the 60-40 and $40-20^{\circ} \mathrm{S}$ domains are least important (similar to $\mathrm{OH}$ structures in Spivakovsky et al., 2000; Lawrence et al., 2001). Most models show increasing L-CH4 in the first few $\mathrm{km}$ above the ocean because of low-level clouds shifting photolysis to the middle troposphere The results for L-O3 show similar patterns of agreement and disagreement among models but emphasize the dominant role of the middle troposphere $(500-800 \mathrm{hPa})$ for $\mathrm{O}_{3}$ loss. $\mathrm{P}-\mathrm{O} 3$ has distinct patterns, demonstrating the importance of larger $\mathrm{NO}_{x}$ values in the upper $(200-500 \mathrm{hPa})$ and lower troposphere $(800-1000 \mathrm{hPa})$, presumably from lightning $\mathrm{NO}_{x}$. Only GMI-CTM lacks lower troposphere sources of $\mathrm{O}_{3}$ at about $180^{\circ} \mathrm{E}$. Overall the models show modest, similar amplitudes (but not always sign) in the bias of A-runs relative to C-runs. Thus we can use the model A-runs to tag each parcel in the ATom measured climatology by its reactivity in the absence of emissions and transport. Clearly these models have largely different chemical climatologies for the middle of the Pacific, and, with the ATom climatology to initialize all six models, we will be able to test whether these differences reflect the initial key species and/or the photochemical components.

Photolysis rates ( $J$-values) are the driving force for reactivity, and we include also a comparison of the $24 \mathrm{~h}$ average $J$ 's (Reactions 2d and 3c) in Fig. 4. The model spread in $J$ $\mathrm{NO}_{2}$ is $20 \%$ and likely due to differences in cloud cover as well as the photolysis module in the model. The wide, factor- of-2 range in $J-\mathrm{O}_{3}\left({ }^{1} D\right)$ cannot be simply explained through differences in clouds or ozone; for example, a $20 \%$ reduction in column $\mathrm{O}_{3}$ gives only a $33 \%$ increase. Such differences will drive a large part of the model differences seen in Fig. 3. For example, the large $J-\mathrm{O}_{3}$ for GISS, and hence large production of $\mathrm{OH}$, can explain in part why GISS has very large L-O3 and P-O3, but not why the L-CH4 (also dependent on $\mathrm{OH}$ ) matches the other models. Surprisingly GEOSChem has an even larger $J-\mathrm{O}_{3}$ but its reactivities are within the range of the other four models. A comparison between the A- and C-runs (not shown) confirms that these two runs have almost identical $J$ 's as expected since these changes in ozone and aerosols over $24 \mathrm{~h}$ between these two simulations will have a small impact on regional average $J$ 's.

While the A-run is clearly asking the modeling groups to make some rather uncomfortable code modifications, these tend to be at the very high level of disabling entire components. Other approaches for indirectly comparing chemical models without transport have been developed (e.g., neural networks in Nicely et al., 2017). We choose the A-run approach as it will allow us to more directly compare modeled reactivities based on the primary CTM-CCM coding and still allows for all models to be initialized with the same chemical composition.

\section{Probability distributions of species and reactivities}

We characterize the heterogeneity in tropospheric chemistry through the joint-probability distributions of the frequency of occurrence of chemical species in air parcels for the six models here. These diagnostics are readily suited to highfrequency in situ observations from an extensive aircraft mission such as ATom, for example see Köppe et al. (2009). This paper then takes a novel approach by focusing on the chemical budgets for tropospheric ozone and methane. In addition to weighting a parcel according to its occurrence or parcel mass, we include a factor that accounts for the modelcalculated reactivities of that parcel. For example, the basic weight of a parcel (moles of air) can be scaled by P-O3 $\left(\mathrm{ppb}\right.$ day $^{-1}$ ), and the final weight is the moles- $\mathrm{O}_{3}$ day $^{-1}$. In this case the sum of weighted parcels in a region gives the moles of $\mathrm{O}_{3}$ produced per day in that region. These reactivities can be calculated with A-runs for both models and measurements. Thus, the modeled and measured probability distributions reflect the parcels most important in determining the chemical budgets in these models and hence the evolution of the atmosphere.

Given the number of key species, the joint-probability distributions are multidimensional, but for the most part we view them in 1-D or 2-D graphs. There is a history of comparing models and measurements using such graphs (Hoor et al., 2002; Hsu et al., 2004; Engel et al., 2006; Pan et al., 2007; Strahan et al., 2007; Parrington et al., 2013; Gaudel et al., 2015). Often the goal is simply to define a linear correla- 

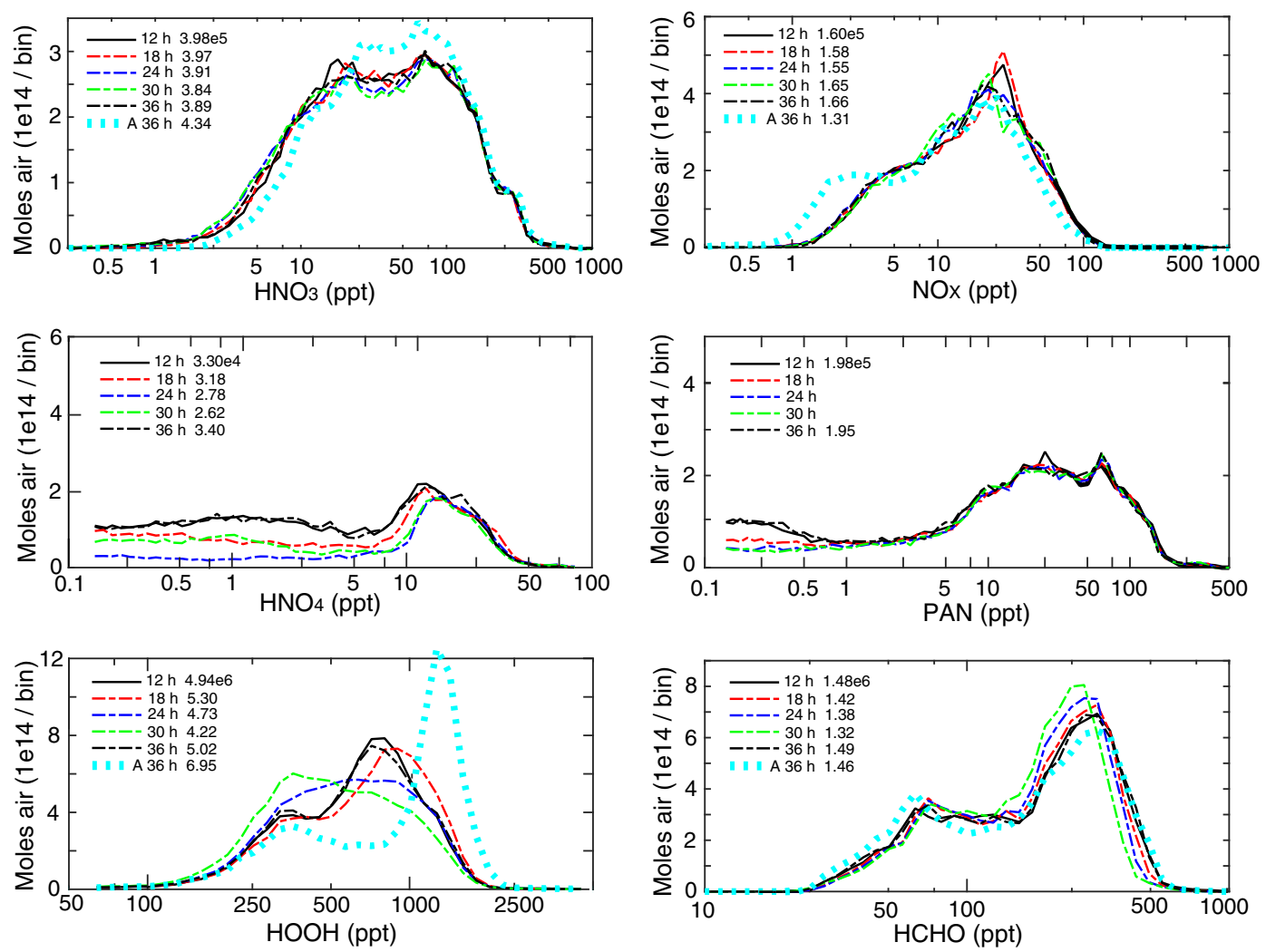

Figure 2. One-dimensional probability distributions for $\mathrm{HNO}_{3}, \mathrm{NO}_{x}, \mathrm{HNO}_{4}, \mathrm{PAN}, \mathrm{HOOH}$, and $\mathrm{HCHO}$ from the UCI-CTM. The domain sampled is the tropical Pacific: $20^{\circ} \mathrm{S}-20^{\circ} \mathrm{N}, 150-210^{\circ} \mathrm{E}, 0-12^{\circ} \mathrm{km}$, on 16 August. The units are moles of air per log-scale bin $(20$ bins per factor of 10). The area under the curve in the log plot is the air mass of the domain, except for $\mathrm{HNO}_{4}$ and PAN for which there are numerous observations below the cutoff at $0.1 \mathrm{ppt}$. Five different times are shown for the C-run: local noon ( $12 \mathrm{~h})$, sunset (18 h), midnight ( $24 \mathrm{~h})$, sunrise $(30 \mathrm{~h})$, and the following noon $(36 \mathrm{~h})$. Also shown is the A-run at noon (12 h, same as C-run) and the following noon (A $36 \mathrm{~h})$. The numbers of moles of the species in the domain are given in the legend.

tion, but in many cases a line fit simply does not describe the heterogeneity (Köppe et al., 2009).

A much more difficult problem is that of representativeness: i.e., how much of the Pacific basin must one sample to get joint-probability distributions similar to that of the whole basin? Can aircraft-measured heterogeneity be compared with models that do not follow the exact flight route for the exact period of measurements (e.g., Hsu et al., 2004)? This latter question is critical if we are to use the ATom measurements to test such a wide variety of CTMs-CCMs. Here, we consider an idealized test case for representativeness where we sample a model as objectively as possible and then compare with different sampling "paths".

One test of representativeness looks at the reactivities sampled along a single longitude and then integrated over latitude-pressure domains. For example, Fig. 1a clearly shows that the instantaneous column integrated L-CH4 varies greatly along longitude transects in the mid-Pacific. The point-to-point variance in 3-D will be very large, but, if we average over regional domains, can we achieve a representative mean value for reactivity? Based on the profiles of reactivity (Fig. 3), we take three pressure domains (boundaries at the surface, 850,500 , and $200 \mathrm{hPa}$, but with stratospheric values screened out by model-designated discriminators) and three latitude domains $\left(60-20^{\circ} \mathrm{S}, 20^{\circ} \mathrm{S}-20^{\circ} \mathrm{N}\right.$, and $\left.20-60^{\circ} \mathrm{N}\right)$. The means (ppb day ${ }^{-1}$ ) and standard deviations $\left(\mathrm{ppb}\right.$ day $^{-1}$ ) of single-longitude sampling across the mid-Pacific $\left(155-233^{\circ} \mathrm{E}\right)$ on 16 August are shown for the UCI-CTM in Table 2 along with the standard deviation (in \%) over the 31 days of August of the daily full-domain average. The standard deviations are a measure of the representativeness of the sampling, by longitude or by day. For L-CH4, the dominant mean loss, $>1 \mathrm{ppb}^{\mathrm{pay}}{ }^{-1}$, is in the surface- $-500 \mathrm{hPa}$ in the tropics and summer (northern) mid-latitudes as seen in Fig. 3. For these regions the standard deviation across the longitudinal samples is of order 6-11\%, whereas outside of these, it is as large as $20 \%$, but the absolute values are small. A similar pattern holds for $\mathrm{L}-\mathrm{O} 3$ with standard deviations in dominant regions of $6-14 \%$. Thus any single, fully sampled longitudinal transect through this domain has a $68 \%$ likelihood of being within $6-14 \%$ of the mid-Pacific average. The variance of $\mathrm{P}-\mathrm{O} 3$ is slightly larger, $8-17 \%$, in part be- 

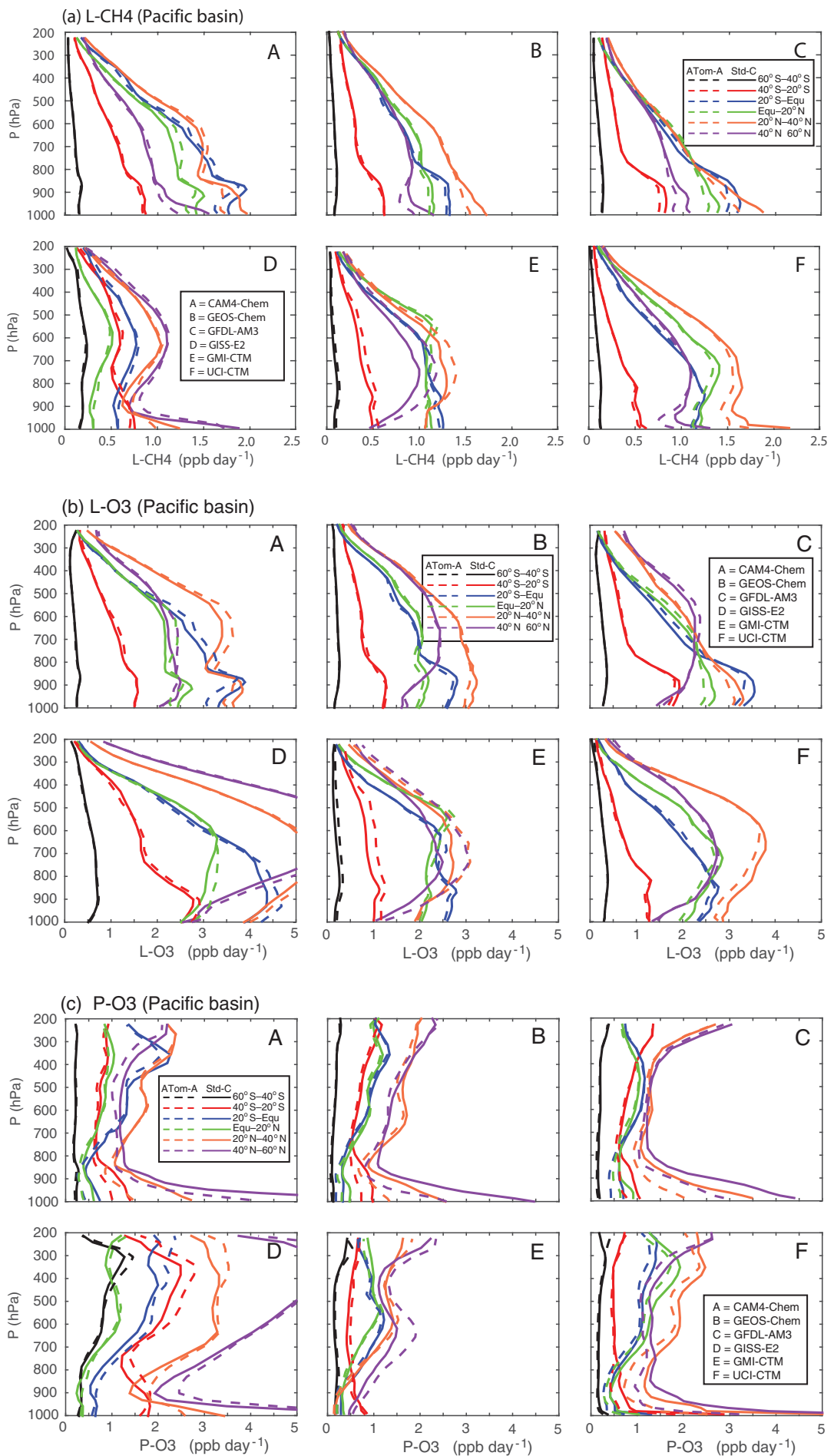

Figure 3. Profiles of reactivity (ppb day ${ }^{-1}$ ) for loss of $\mathrm{CH}_{4}$ ( $\mathrm{L}-\mathrm{CH} 4$, top panel), loss of $\mathrm{O}_{3}$ ( $\mathrm{L}-\mathrm{O} 3$, middle panel), and production of $\mathrm{O}_{3}$ (P-O3, bottom panel) from six global models (Table 1). Cells from each model grid are averaged over $20^{\circ}$ latitude domains (different colors, see legend), longitudes from 150 to $210^{\circ} \mathrm{E}$, and for the single day of 16 August. Years vary by model, see text. Solid lines are standard model simulations (C-runs) with the values representing air that passed through the cell over $24 \mathrm{~h}$. Dashed lines are the no-transport, no-emissions A-runs that keep the initialized chemical values in the same cell over $24 \mathrm{~h}$. 

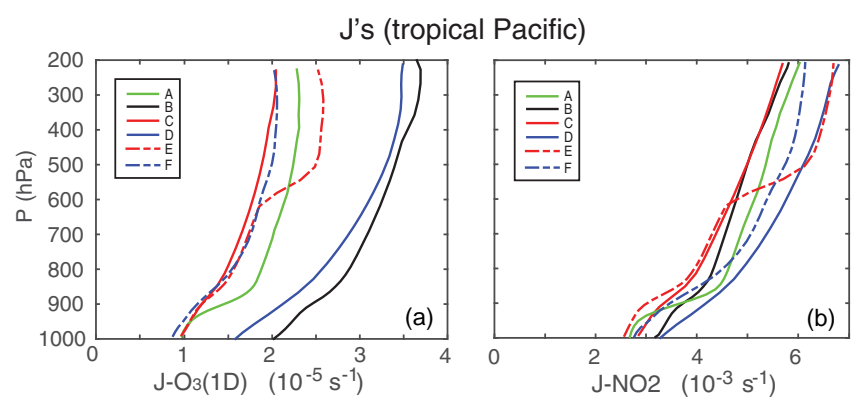

Figure 4. Modeled $24 \mathrm{~h}$ average $J$-values for $\mathrm{O}_{3}+$ $h v=>\mathrm{O}\left({ }^{1} D\right)+\mathrm{O}_{2} \quad\left(\mathbf{a}, \mathrm{s}^{-1}\right)$ and $\mathrm{NO}_{2}+h v=>\mathrm{NO}+\mathrm{O} \quad(\mathbf{b}$, $\left.\mathrm{s}^{-1}\right)$ for the tropical Pacific $\left(20^{\circ} \mathrm{S}-20^{\circ} \mathrm{N}, 150-210^{\circ} \mathrm{E}\right)$. See Fig. 3 and Table 1 for model codes.

cause $\mathrm{P}-\mathrm{O} 3$ depends on the less-frequent high- $\mathrm{NO}_{x}$ regions. Assembling a representative sampling of $\mathrm{P}-\mathrm{O} 3$ at the same $\%$ level as L-O3 will be slightly more difficult. Such singletransect representativeness is about as good as we can expect. Thus, model-model differences comparing individual transects from each model would not be significant unless they exceed these percentages. Averaging over the basin and/or several days should resolve model differences at finer scales. The day-to-day standard deviation for the mid-Pacific averages in Table 2 is shown in percent; it is smaller than across individual longitudinal transects for a given day; and in key regions (surface to $500 \mathrm{hPa}, 20^{\circ} \mathrm{S}$ to $60^{\circ} \mathrm{N}$ ) it ranges from $1-4 \%$ for $\mathrm{L}-\mathrm{CH} 4$ to $2-8 \%$ for P-O3. A remaining question (not resolved with the datasets assembled here) is the yearto-year variance of basin-wide reactivities perhaps associated with the El Niño-Southern Oscillation.

The six models' 1-D probability distributions for $\mathrm{O}_{3}, \mathrm{CO}$, $\mathrm{NO}_{x}$, and $\mathrm{HCHO}$ over the tropical mid-Pacific basin are shown in Fig. 5, and simple statistics (mean $\pm \mathrm{SD}$ ) are presented in the Supplement Table S5. Modeled data are sampled on the native grid of each model and not interpolated. This approach readily allows us to compare different models. Both 1-D and 2-D distributions presented here are sorted into $20 \mathrm{log}$-spaced bins per each factor of 10 (decade) in abundance (ppb or ppt). The dashes in the upper/lower rows of Fig. 5 indicate widths of these bins on each plot. For example, $\mathrm{NO}_{x}$ distributions cover more than 3 decades (very small dashes), while the $\mathrm{CO}$ covers less than a decade (wide dashes). In the first row labeled "AIR", each grid cell is weighted by its size in moles, and thus the plot shows petamoles per logarithmic bin. In each subsequent row, the cells are weighted by the reactivity (L-CH4, L-O3, P-O3) in moles day ${ }^{-1}$, plotting thus megamoles per day per bin.

The AIR plots show clear model differences. Models A and $\mathrm{B}$ have much greater frequency of $\mathrm{O}_{3}$ occurrence from 50-150 ppb, and half the models (B, D, E) show a reasonable frequency of $\mathrm{O}_{3}$ at $10 \mathrm{ppb}$ and less, as might be expected in the tropical Pacific boundary layer (Kley et al., 1996; Singh et al., 1996; Nicely et al., 2016). For CO, model
A shows unusually low abundances. For $\mathrm{NO}_{x}$, models $\mathrm{C}$ and $\mathrm{F}$ lack the $\mathrm{NO}_{x}$ below $2.5 \mathrm{ppt}$ that others have. The models are quite similar for $\mathrm{HCHO}$, except for $\mathrm{D}$, which has an unusually symmetric distribution and much lower abundances. When reactivity weighted, new features are found. Note that the area under the AIR-weighted curve is the same for all models, but the area in reactivity-weighted 1-D plots is each model's total reactivity (moles day ${ }^{-1}$ ). Model D has lower values overall for L-CH4 compared with the other models, but it is similar or even slightly higher for $\mathrm{L}-\mathrm{O} 3$ and $\mathrm{P}-$ O3. The high- $\mathrm{O}_{3}$ abundances in A remain equally important when weighted by any reactivity, but those in B become less important for L-CH4 and L-O3, but even more important for P-O3. This unusual feature adds a new dimension to diagnosing and understanding model differences. The reactivity weighting of the $\mathrm{CO}$ distribution does not show anything unusual. The $\mathrm{NO}_{x}$ 1-D plots show that $\mathrm{L}-\mathrm{CH} 4$ is more heavily weighed to low $\mathrm{NO}_{x}$ values than is L-O3, but $\mathrm{P}-\mathrm{O} 3$ is weighted strongly to the higher $\mathrm{NO}_{x}$ abundances $(>10 \mathrm{ppt})$ as expected. The $\mathrm{HCHO}$ reactivity weights in the opposite direction with high abundances ( $>200 \mathrm{ppt}$ ) favoring $\mathrm{L}-\mathrm{CH} 4$ and L-O3 but lower ones favoring P-O3, probably because the lower ones are from the upper troposphere where colder temperatures suppress both L-CH4 and L-O3 (Fig. 3). The results from the full probability distribution (Fig. 5) are mostly represented in the central statistics of Table S5. The reactivity weighting adds a new dimension to the diagnostics, and after the ATom dataset becomes available it would be productive to make a more detailed comparison that identifies the location and other key species controlling these shifts in reactivity.

These new diagnostics do not instantly identify the cause of model differences, but they do add a new dimension. For example, if we seek to understand why model D is different, we can look at global budgets: both models A and $\mathrm{D}$ have $\mathrm{P}-\mathrm{O} 3$ and $\mathrm{L}-\mathrm{O} 3$ tropospheric means between 2.5 and $3.5 \mathrm{ppb}$ day $^{-1}$, whereas the other four models have values between 1.0 and 2.0. The global $\mathrm{L}-\mathrm{CH} 4-0.50$ to $0.65 \mathrm{ppb}$ day $^{-1}$ - is similar for all models, with $\mathrm{D}$ in the middle. So globally, models B and D are similar, but, in the midPacific, they are distinct with model D having much lower $\mathrm{L}-\mathrm{CH} 4$ values in the tropics and especially the lower tropics (Fig. 3, see also Fig. S1 of Naik et al., 2013b). $\mathrm{CH}_{4}$ loss is a major source of $\mathrm{HCHO}$ in the unpolluted atmosphere and this may partly explain D's lower values of tropical HCHO compared with other models. Some of the reduced tropical reactivity in D may be caused by more low clouds in the tropics, and this is apparent in the more rapid fall off in $J-\mathrm{O}_{3}\left({ }^{1} D\right)$ compared with other models (Fig. 4); yet models B and D (not $\mathrm{A}$ and $\mathrm{D}$ as found in $\mathrm{L}-\mathrm{O} 3$ and $\mathrm{P}-\mathrm{O} 3$ ) have much higher values of $J-\mathrm{O}_{3}\left({ }^{1} D\right)$. With the ATom A-run approach we will be able to remove differences caused by the widely ranging chemical climatologies of species (e.g., seen in Figs. 5, 6, 8) and more directly trace the range of results to the models' basic photolysis and kinetics. 
9092

M. J. Prather et al.: Global atmospheric chemistry - which air matters
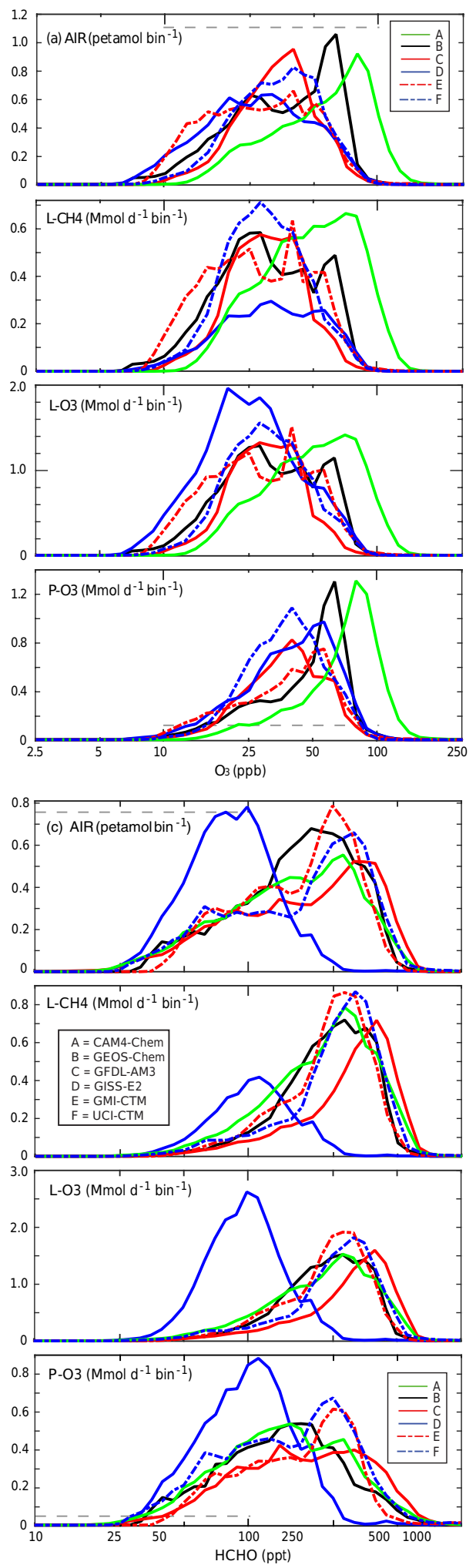
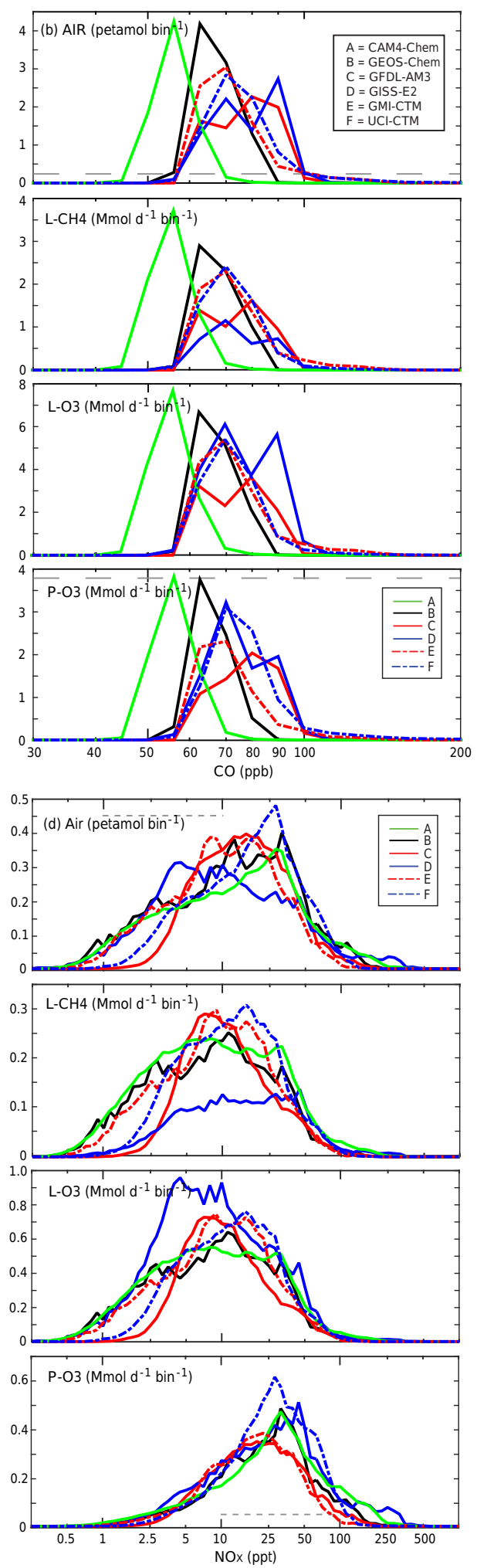

Figure 5. Six modeled 1-D probability distributions for $\mathrm{O}_{3}, \mathrm{CO}, \mathrm{NO}_{x}$, and $\mathrm{HCHO}$, where the air parcels have been weighted by air mass (row 1), L-CH4 (row 2), L-O3 (row 3), and P-O3 (row 4). The domain being sampled in the models is the tropical Pacific: $20^{\circ} \mathrm{S}-20^{\circ} \mathrm{N}$, $150-210^{\circ} \mathrm{E}, 0.5-12 \mathrm{~km}$. Units for the air weighting are petamoles per bin where the bins are set at 20 per decade (sizes marked by dashed lines in upper or lower panels) and Moles per bin per day for the reactivity-weighted plots (rows 2-4).

Atmos. Chem. Phys., 17, 9081-9102, 2017

www.atmos-chem-phys.net/17/9081/2017/ 
Table 2. Representativeness of reactivities ( $\mathrm{L}-\mathrm{CH} 4, \mathrm{~L}-\mathrm{O} 3$, and $\mathrm{P}-\mathrm{O} 3$ - all in ppb day ${ }^{-1}$ ) averaged over three latitude and three pressure domains over the central Pacific $\left(155-233^{\circ} \mathrm{E}\right)$. The first standard deviation (ppb day $\left.{ }^{-1}\right)$ is over the different longitudinal transects on midAugust; and the second $(\%)$ is for the average across longitudes sampled over 31 days of August.

\begin{tabular}{llll}
\hline L-CH4 $\left(\mathrm{ppb} \mathrm{day}^{-1}\right)$ & $60-20^{\circ} \mathrm{S}$ & $20^{\circ} \mathrm{S}-20^{\circ} \mathrm{N}$ & $20-60^{\circ} \mathrm{N}$ \\
\hline $500-200 \mathrm{hPa}$ & $0.08 \pm 0.02 \pm 8 \%$ & $0.36 \pm 0.06 \pm 7 \%$ & $0.45 \pm 0.08 \pm 3 \%$ \\
$850-500 \mathrm{hPa}$ & $0.28 \pm 0.04 \pm 6 \%$ & $1.08 \pm 0.07 \pm 4 \%$ & $1.26 \pm 0.12 \pm 2 \%$ \\
Surf-850 hPa & $0.35 \pm 0.03 \pm 4 \%$ & $1.21 \pm 0.13 \pm 2 \%$ & $1.44 \pm 0.11 \pm 1 \%$ \\
\hline $\mathrm{L}-03\left(\mathrm{ppb} \mathrm{day}{ }^{-1}\right)$ & & & \\
\hline $500-200 \mathrm{hPa}$ & $0.24 \pm 0.03 \pm 7 \%$ & $0.74 \pm 0.15 \pm 8 \%$ & $1.35 \pm 0.27 \pm 4 \%$ \\
$850-500 \mathrm{hPa}$ & $0.69 \pm 0.08 \pm 6 \%$ & $2.28 \pm 0.13 \pm 6 \%$ & $3.01 \pm 0.43 \pm 3 \%$ \\
Surf- $850 \mathrm{hPa}$ & $0.86 \pm 0.06 \pm 4 \%$ & $2.46 \pm 0.32 \pm 3 \%$ & $2.60 \pm 0.22 \pm 3 \%$ \\
\hline $\mathrm{P}-\mathrm{O} 3\left(\mathrm{ppb} \mathrm{day}{ }^{-1}\right)$ & & & \\
\hline $500-200 \mathrm{hPa}$ & $0.35 \pm 0.04 \pm 10 \%$ & $1.37 \pm 0.18 \pm 7 \%$ & $1.78 \pm 0.30 \pm 4 \%$ \\
$850-500 \mathrm{hPa}$ & $0.36 \pm 0.06 \pm 9 \%$ & $0.92 \pm 0.08 \pm 8 \%$ & $1.46 \pm 0.13 \pm 2 \%$ \\
Surf-850 hPa & $0.32 \pm 0.20 \pm 9 \%$ & $0.43 \pm 0.09 \pm 2 \%$ & $2.34 \pm 0.33 \pm 3 \%$ \\
\hline
\end{tabular}

Results are from the UCI-CTM C-runs for 16 August and 1-31 August. The $155-233^{\circ} \mathrm{E}$ domain includes 69 longitudinal transects. All tropospheric grid cells in the domain are sampled equally and weighted by mass. The period 1-31 August shows trends in some domains as the sun moves southward, and this was removed with a line fit to calculate the standard deviation over the month. Results for the A-runs (not shown) differ in mean and standard deviation by a few percent.
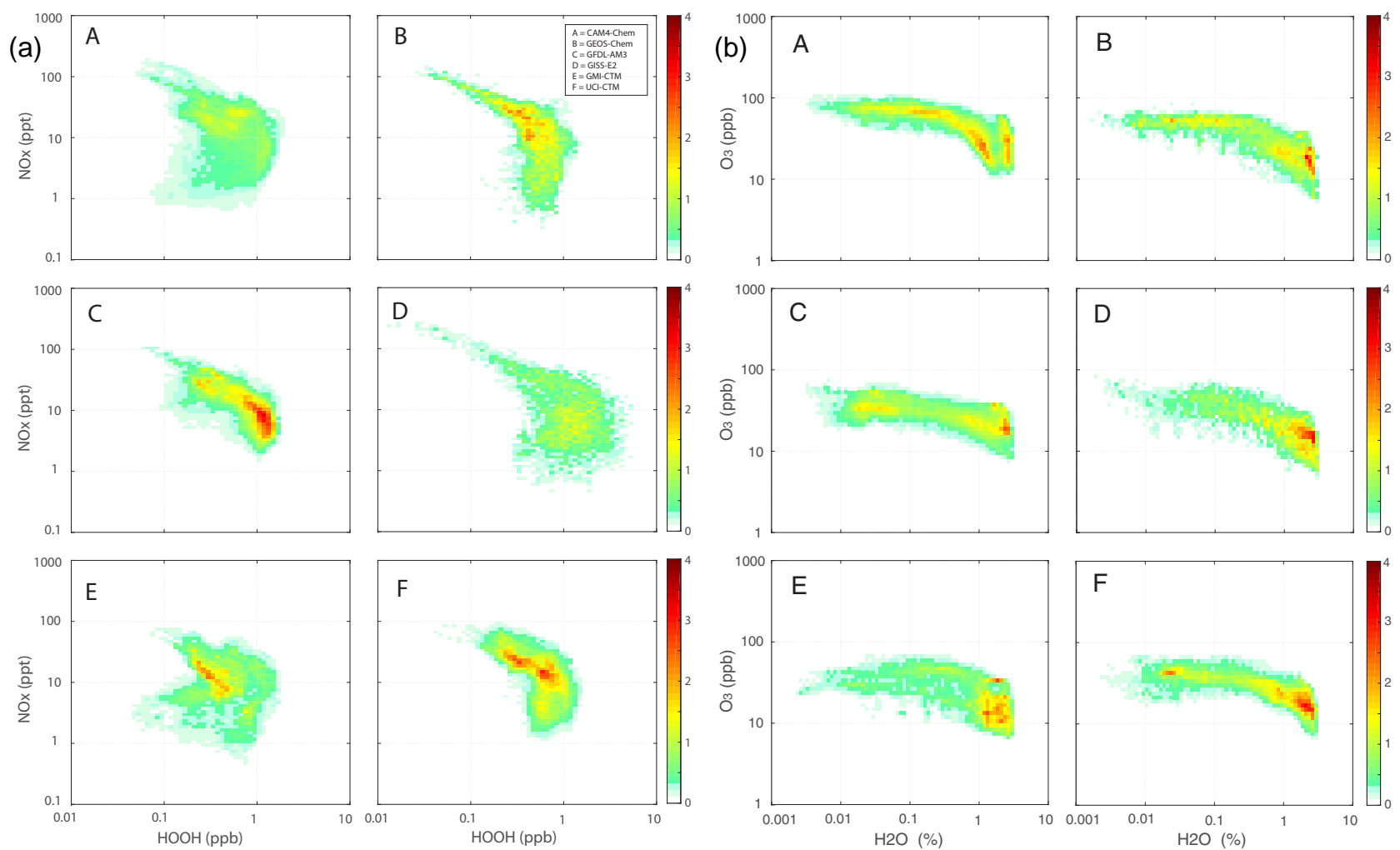

Figure 6. (a) Six modeled 2-D probability distributions for $\mathrm{NO}_{x}$ vs. $\mathrm{HOOH}$ as weighted by air mass. These are the initial chemical abundances for each model and hence the same for A- and C-runs. All grid cells were binned at 20 per decade in species abundance (mole fraction, ppt for $\mathrm{NO}_{x}$, ppb for $\mathrm{HOOH}$ ). The density value for each plot is scaled so that a uniform distribution over exactly 1 decade in both species would give the yellow-green color of 1.0. The domain being sampled in the models is the tropical Pacific: $20^{\circ} \mathrm{S}-20^{\circ} \mathrm{N}, 150-210^{\circ} \mathrm{E}$, 0.5-12 km. Model A = CAM4-Chem; B = GEOS-Chem; C= GFDL-AM3; D = GISS-E2; E= GMI-CTM; F= UCI-CTM. (b) Six modeled 2-D probability distributions for $\mathrm{O}_{3}$ vs. $\mathrm{H}_{2} \mathrm{O}$ as weighted by air mass. This color-bar scale differs slightly from other 2-D plots. See (a). 

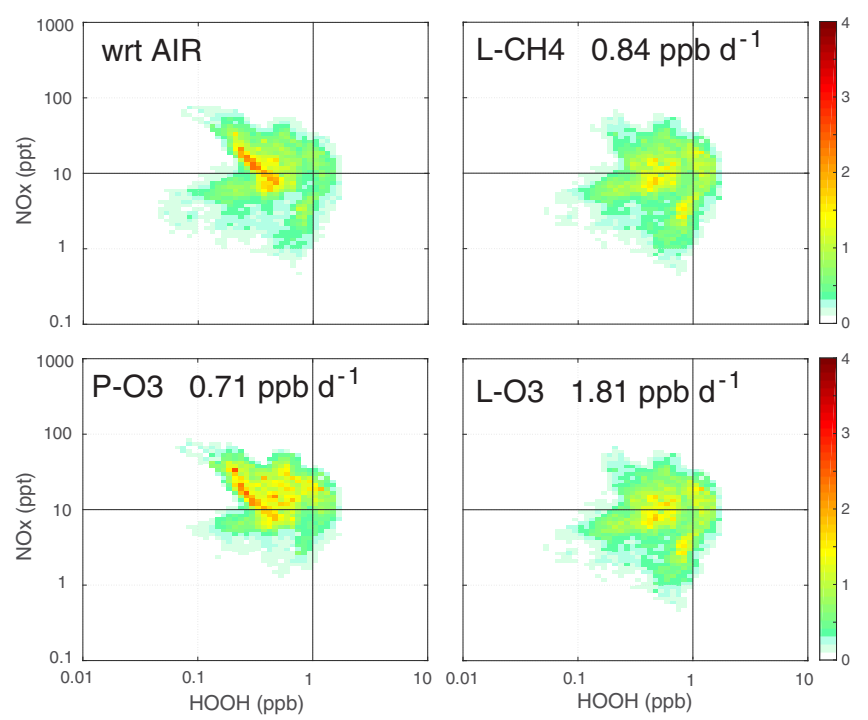

Figure 7. Model E (GMI CTM) 2-D probability distributions from A-run for $\mathrm{NO}_{x}$ vs. $\mathrm{HOOH}$ as weighted by air mass, L-CH4, L-O3, and P-O3. The domain being sampled is $20^{\circ} \mathrm{S}-20^{\circ} \mathrm{N}, 150-210^{\circ} \mathrm{E}$, $0.5-12$ km, see Fig. 6 a.

The 2-D distributions simply weighted by AIR show remarkable structures that differ significantly across the models, as shown in Fig. 6, with summary statistics in Table S6. All 2-D plots use the same 20-per-decade log scale as in the $1-\mathrm{D}$ analysis, and they are normalized such that if all parcels are distributed uniformly within a $20 \times 20$ square (e.g., $0.1-$ $1.0 \mathrm{ppb} \mathrm{HOOH}, 10-100 \mathrm{ppt} \mathrm{NO}_{x}$ ) the arbitrary density value would be 1 (a yellow-green color in Figs. 6-7). Thus, the reactivity-weighted 2-D plots are renormalized and do not reflect the individual model's total reactivity. In Fig. 6a the AIR-weighted $\mathrm{NO}_{x}-\mathrm{HOOH}$ plots show a boomerang structure with greatly varying degrees of concentration about some points in the center (reddish regions). For example, models $\mathrm{A}$ and $\mathrm{D}$ show a very diffuse distribution with a much wider spread in $\mathrm{HOOH}$ values at lower $\mathrm{NO}_{x}$. Even for the four models with a central $\left(\mathrm{NO}_{x}, \mathrm{HOOH}\right)$-line defining a peak frequency of occurrence, this line occurs at different locations. The $\mathrm{O}_{3}-\mathrm{H}_{2} \mathrm{O}$ density plots (Fig. 6b) show examples of highly standard and well-measured species with extreme distributions: $\mathrm{O}_{3}$ fall within 1 decade throughout most of the troposphere, but $\mathrm{H}_{2} \mathrm{O}$ easily spans 3 . Several show the bimodality of many parcels with low $\mathrm{O}_{3}$ with high $\mathrm{H}_{2} \mathrm{O}$ (marine boundary layer and above) and a second peak at higher $\mathrm{O}_{3}$ and dry. For example, $\mathrm{C}$ and $\mathrm{E}$ look very much alike, but $\mathrm{B}$ has these two peaks more separated, and $\mathrm{E}$ has a much broader spread in upper tropospheric $\mathrm{O}_{3}$ abundances.

Simple statistics for the probability distributions in Fig. 6 are presented in the Tables S6a, b, c, d. Comparisons of the 1$\mathrm{D}$ distributions show that the log-normal distribution in mole fraction (mean $\mu$ and standard deviation $\sigma$ ) as represented by $(\mu-\sigma, \mu, \mu+\sigma)$ is for the most part very close to the equiva- lent percentile distribution $(16,50,84 \%)$. For 2-D summary statistics, we introduce a fitted ellipse centered at the mean value centroid $\left(X_{0}, Y_{0}\right)$ with semimajor and semiminor axes defined as the standard deviation in the two orthogonal axes $\left(\sigma_{X}, \sigma_{Y}\right)$ rotated to find the flattest ellipse (i.e., maximum of $\left.\sigma_{X} / \sigma_{Y}\right)$. The values of centroid, semimajor and semiminor axes, and the degree of rotation are given in Tables S6 for all plots in Fig. 6. An example showing a fitted ellipse on top of the 2-D probability distribution is given in Fig. S1, and the ellipses for all six model distributions in Fig. 6a and b are plotted together in Fig. S2a and b, respectively. These ellipses can provide a more direct and simple comparison of the central distributions of the models and support the discussion of Fig. 6 above.

These plots include all altitudes that can be sampled by the ATom flights. When comparisons with ATom data are made, it will be useful to identify discrepancies in the 2-D plots by separating altitude regions.

The 2-D plots can change the emphasis of certain regions when weighted by reactivity. For example, we take the GMICTM modeled $\mathrm{NO}_{x}-\mathrm{HOOH}$ density (Fig. 6a, panel E) and show the reactivity weightings in Fig. 7. With AIR weighting, the quasi-boomerang has a strong central line with a negative slope. With P-O3, a much broader range is seen and the peak occurrence shifts to lower $\mathrm{HOOH}$ values and somewhat even to lower $\mathrm{NO}_{x}$ values. With L-CH4, the line disappears and a galaxy-like pattern widens the range of parcels, picking up lower $\mathrm{NO}_{x}$ values in two spiral arms. The L-O3 weighting is similar to $\mathrm{L}-\mathrm{CH} 4$, and differences are discernable only in small features. Clearly, species other than $\mathrm{NO}_{x}$ and $\mathrm{HOOH}$ determine the reactivity of parcels, and thus other 2-D plots will add new information. We anticipate that ATom measurements will be plotted not only with AIR weightings but also with reactivities calculated for that air parcel with these models (Auvray et al., 2007).

The 2-D plots shown here intentionally included all air parcels over the mid-Pacific to ensure that a robust distribution was obtained (see Table 2). If we have only a single longitude slice as in ATom, then will these be so clearly defined? We examine this representativeness test by subsampling two models (C: GFDL-AM3 and F: UCI-CTM) at longitudes of $150,165,180,195$, and $210^{\circ} \mathrm{E}$ in Fig. 8 to compare with the average over the mid-Pacific domain. The densities are renormalized and show similar peaks and patterns, but of course there is more pixel-level noise and some differences. The transect at $150^{\circ} \mathrm{E}$ is clearly less representative of the midPacific, which is understandable since that longitude includes Papua New Guinea and eastern tropical Australia. Most importantly, the differences for $165-210^{\circ} \mathrm{E}$ are less than those across the six models (Fig. 7a). We need to develop an objective measure for comparing 2-D plots between models and ATom measurements and for judging if their differences are within the range of representativeness. Fortunately, the fitted ellipses provide a remarkably simple approach to evaluating the similarities and differences in these different tran- 

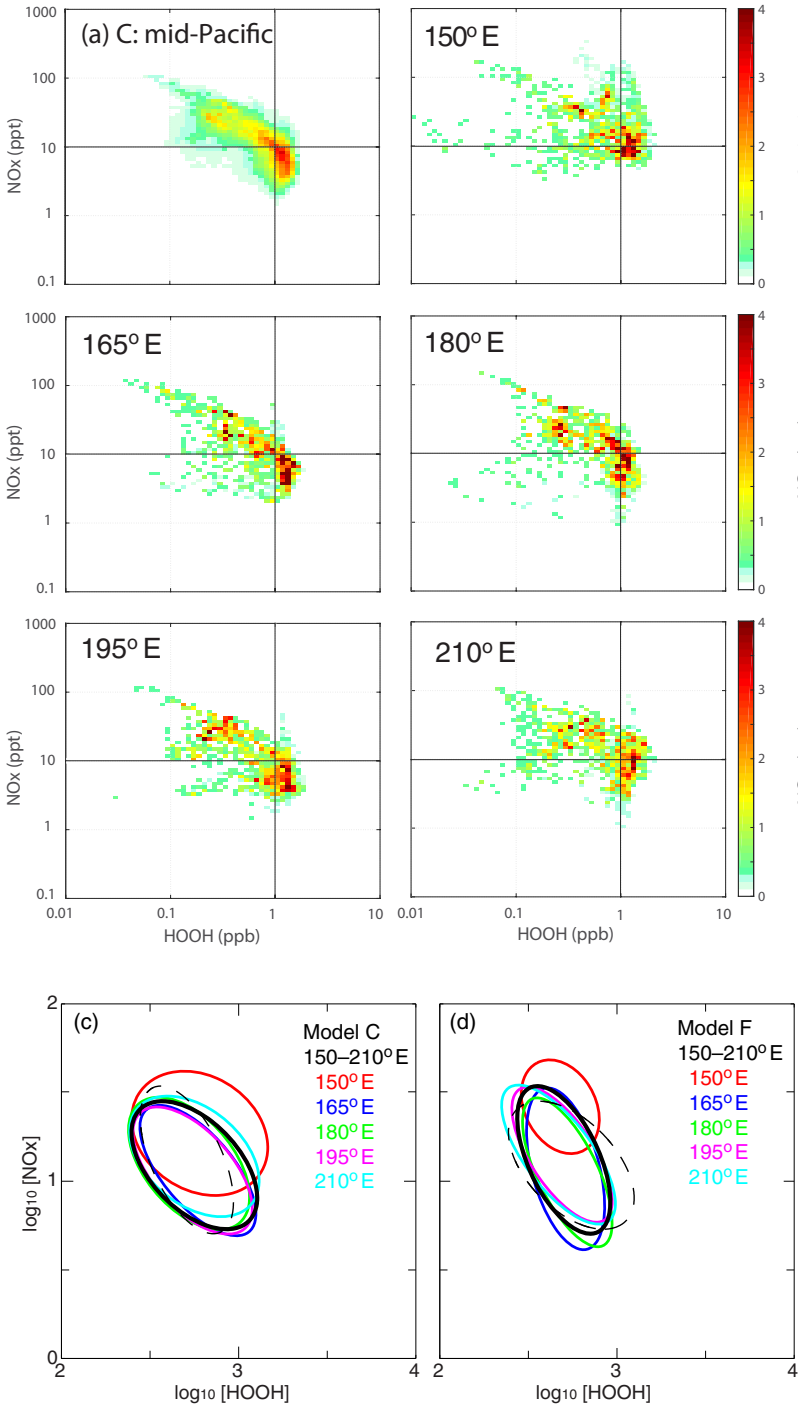
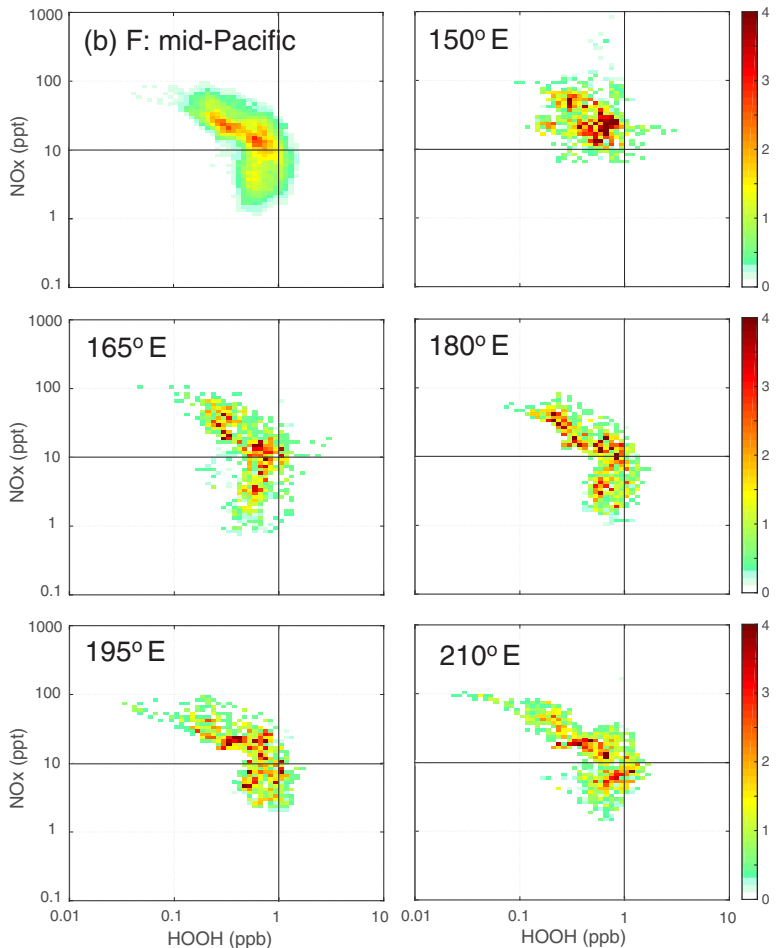

Figure 8. AIR-weighted 2-D probability distributions for $\mathrm{NO}_{x}$ vs. $\mathrm{HOOH}$ averaged over tropical Pacific block $\left(150-210^{\circ} \mathrm{E}, 20^{\circ} \mathrm{S}-20^{\circ} \mathrm{N}\right.$, 0-12 km) and for different single-longitude transects from 150-210 ${ }^{\circ} \mathrm{E}$, shown for models (a) C (GFDL-AM3) and (b) F (UCI-CTM). The fitted 2-D ellipses are shown for the full block (thick black line) and five longitude transects (colored lines) for models (c) $\mathrm{C}$ and (d) $\mathrm{F}$. The block ellipse for the other model is shown as a thin black dashed line.

sects and are plotted in Fig. S8c, d. For both models C and F we see that the central Pacific single transects $(165,180,195$, $\left.210^{\circ} \mathrm{E}\right)$ with overlapping ellipses match the full block of data $\left(150-210^{\circ} \mathrm{E}\right)$. In terms of overlapping area, the single transects overlap the full block at the 86-94\% level, whereas the $150^{\circ} \mathrm{E}$ transect is distinctly different with overlap of only 42 (F) and $63 \%(\mathrm{C})$. The full-block ellipse from the other model is plotted in Fig. 8c, d (dashed lines) to show that the models can be distinguished from even single transects (overlap of $60 \%)$.

\section{Discussion and preparation for the ATom dataset}

This paper is based on the underlying premise that highfrequency profiling of the key species controlling the daily average reactivity of individual air parcels throughout the remote ocean basins can provide a unique, objectively sampled chemical climatology identifying those air parcels that matter, i.e., are most important in controlling methane and tropospheric ozone. Such data will further provide the most rigorous testing and diagnosis of the global chemistry models, in particular the chemistry-climate models, which require a climatology.

Here we present a six model comparison using this new approach. We outline the model development (i.e., the A- 

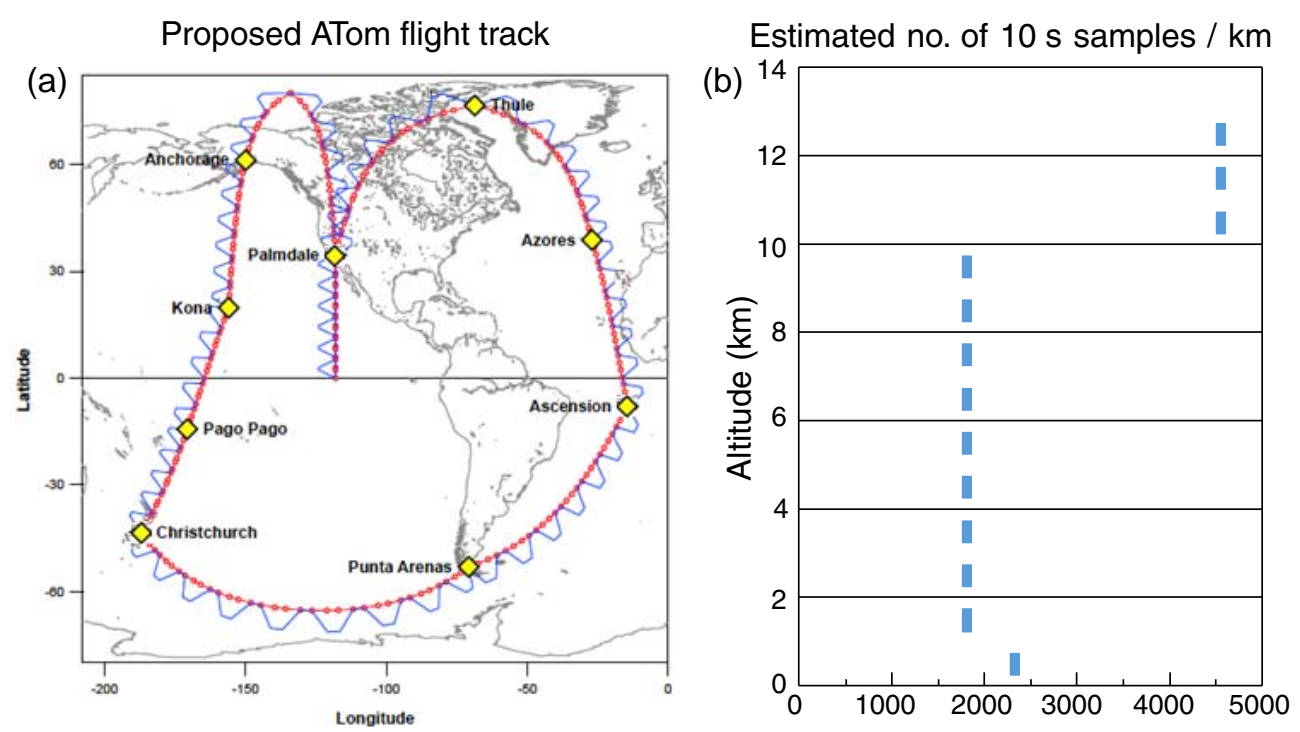

Figure 9. ATom proposed flight tracks (a) and estimated sampling frequency by $1 \mathrm{~km}$ altitude bins (b). The actual flights are somewhat altered. The altitude sampling is based on the proposed $\sim 90 \mathrm{~h}$ of flight time, $\sim 180$ profiles taking $\sim 35$ min for each pair of climb-descend, and 5 min spent each profile in the marine boundary layer. For up-to-date information on the ATom mission and deployments, see https: //espo.nasa.gov/missions/atom/content/ATom.

runs) that enables global chemistry models to readily use high-frequency measurements from aircraft campaigns like the NASA ATom mission to calculate the chemical reactivity in individual parcels and over chemical regimes. The multimodel comparison has already identified some commonalities and highlighted several differences among the models in their calculation of tropospheric ozone and methane tendencies. For models that are outliers in particular diagnostics, it is a challenge for them to identify the cause within their own model and perhaps explain why the more common results are the ones in error. A test of these models, isolating the photochemical module by using A-runs with the same string of simulated measurements, is underway.

The multi-model comparison has provided a range of scientific results:

- All six models show distinctly different reactivity profiles in the Pacific basin, with model-model differences much larger than the A-run and C-run differences; models that look similar in one reactivity can appear different in another (e.g., L-CH4 in B and C vs. L-O3).

- It is hard to find a consistent pattern in P-O3; we attribute these model differences to wide variations in $\mathrm{NO}_{x}$ abundances over the remote Pacific.

- $J$-values in the tropics, particularly $J-\mathrm{O}(1-\mathrm{D})$ (Reaction 3d), differ widely across the six models; this is unexpected considering the general agreement with photolysis model comparisons (PhotoComp, 2010) and indicates that implementation of the photolysis codes in different models may be inconsistent.
- Probability distributions for the tropics show robust differences with clear outliers, different models are singled out for different species (model A for $\mathrm{CO}$ and $\mathrm{O}_{3}, \mathrm{D}$ for $\mathrm{HCHO}$ and $\mathrm{NO}_{x}$ ), and surprisingly the water vapor shows a large range across models.

- Reactivity-weighted probability distributions show shifts that might be expected, based on L-CH4 and L-O3 occurring primarily in the lower mid-troposphere and $\mathrm{P}-\mathrm{O} 3$ occurring near the surface and in the upper troposphere; however, not all models show the same shift, implying a very different distribution of reactivity and/or dependence on the key species.

- Representativeness, specifically the ability of a few Pacific transects to provide a chemical climatology for the entire basin, was tested extensively in model $\mathrm{F}$ for average reactivities across different longitudes and days and showed modest variability; when compared in terms of 2-D probability densities and fitted ellipses, two models showed that longitudinal transects from 165 to $210^{\circ} \mathrm{E}$ were nearly identical, yet distinct from the other model.

The 1-D and 2-D probability distributions of key species are sufficiently diverse across the models so that climatology measurements, like those from ATom, will easily be able to differentiate among them and likely identify specific model discrepancies. For example, in Fig. 6a models A and E are alone in identifying a population of parcels with low- $\mathrm{HOOH}$ that also have low- $\mathrm{NO}_{x}$. If this is not found in the observations, then we have some clues (also looking at other key variables like in Fig. 6b) that will identify locations and processes. Further, by looking at the reactivity of these parcels 
(Fig. 7), we can find that this region is important for methane and ozone loss. Some work remains in establishing just how close is good enough in matching 2-D (and multi-D) probability distributions of the key species, although the overlap of the 2-D fitted ellipses begins to address this.

There are other ATom measurements beyond just key species that might prove useful as climatological tests for the models. The $\mathrm{OH}$ loss frequency (L-OH, Sinha et al., 2008; Mao et al., 2009) is primarily determined by the longer-lived reactive species listed here, which can be derived from the key species, but it is not really a product of the 3-D models. Effectively, L-OH provides a climatology of a weighted basket of species. The models' predicted L-OH using their own key species could be tested with the L-OH observations, but then we are just testing the model's key species and our direct comparisons are more useful. Actinic fluxes and thus $J$-values are being measured by ATom and can be analyzed on a case-by-case basis (Palancar et al., 2011) to assess the role of clouds in determining instantaneous reactivity. To be useful as a climatology, the models would need to develop statistics on how the observed $J$-values (with clouds) deviated from clear-sky (modeled) values, thus checking if the photolysis effect of the cloud statistics in the models is similar that observed. In this case ATom is probably one of the only useful datasets because flight plans were made independent of clear or cloudy conditions (except for aircraft safety). At present there is no clear path to use either L-OH or $J$ 's to improve the climatologies of $\mathrm{L}-\mathrm{CH} 4, \mathrm{~L}-\mathrm{O} 3$, and $\mathrm{P}-\mathrm{O} 3$.

ATom involves four deployments: ATom-1 completed in August 2016, ATom-2 completed in February 2017, ATom3 scheduled for October 2017, and ATom-4 completes in May 2018. ATom was successful in completing all flights with instruments working, acquiring well over $90 \%$ of the proposed dataset, and measuring more than $3000010 \mathrm{~s}$ air parcels. A quick look at the pre-ATom planned flight tracks and sampling in Fig. 9 shows the coverage of the ocean basins, the large numbers of profiles, and the sampling frequency as a function of altitude. The expected release of ATom-1 data is mid-2017 and will include the global chemical model products discussed here. These measurements and analysis will provide a new approach for understanding which air matters.

Data availability. The netcdf files of the model output that is analyzed here are posted with the NASA ATom mission measurements. The publicly available ATom data can be found at https: //espoarchive.nasa.gov/archive/browse/atom. The .nc files are located at https://espoarchive.nasa.gov/archive/browse/atom/Model. A DOI has just been registered for the ATom data including model data (https://doi.org/10.5067/Aircraft/ATom/TraceGas_ Aerosol_Global_Distribution), and in time the data will be migrated to that DOI. The Supplement related to this article is available online
at https://doi.org/10.5194/acp-17-9081-2017-supplement.

Competing interests. The authors declare that they have no conflict of interest.

Acknowledgements. This work was supported by NASA funding of the EVS2 Atmospheric Tomography (ATom) mission through a range of specific funding mechanisms to UC Irvine (NNX15AG57A), NASAS GSFC, Columbia U, NCAR, and Harvard U. Michael J. Prather thanks Daniel Cariolle (CERFACS) and Valérie Thouret (Laboratoire d'Aerologie) for hosting his sabbatical, during which this paper was written and submitted.

Edited by: Marc von Hobe

Reviewed by: two anonymous referees

\section{References}

Allen, D., Pickering, K., and Fox-Rabinovitz, M.: Evaluation of pollutant outflow and CO sources during TRACE-P using model-calculated, aircraft-based, and Measurements of Pollution in the Troposphere (MOPITT)-derived CO concentrations, J. Geophys. Res.-Atmos., 109, D15S03, https://doi.org/10.1029/2003jd004250, 2004.

Apel, E. C., Olson, J. R., Crawford, J. H., Hornbrook, R. S., Hills, A. J., Cantrell, C. A., Emmons, L. K., Knapp, D. J., Hall, S., Mauldin, R. L., Weinheimer, A. J., Fried, A., Blake, D. R., Crounse, J. D., St Clair, J. M., Wennberg, P. O., Diskin, G. S., Fuelberg, H. E., Wisthaler, A., Mikoviny, T., Brune, W., and Riemer, D. D.: Impact of the deep convection of isoprene and other reactive trace species on radicals and ozone in the upper troposphere, Atmos. Chem. Phys., 12, 1135-1150, https://doi.org/10.5194/acp-12-1135-2012, 2012.

Auvray, M., Bey, I., Llull, E., Schultz, M. G., and Rast, S.: A model investigation of tropospheric ozone chemical tendencies in longrange transported pollution plumes, J. Geophys. Res.-Atmos., 112, D05304, https://doi.org/10.1029/2006jd007137, 2007.

Barnes, E. A. and Fiore, A. M.: Surface ozone variability and the jet position: Implications for projecting future air quality, Geophys. Res. Lett., 40, 2839-2844, https://doi.org/10.1002/Grl.50411, 2013.

Bey, I., Jacob, D. J., Yantosca, R. M., Logan, J. A., Field, B. D., Fiore, A. M., Li, Q. B., Liu, H. G. Y., Mickley, L. J., and Schultz, M. G.: Global modeling of tropospheric chemistry with assimilated meteorology: Model description and evaluation, J. Geophys. Res.-Atmos., 106, 23073-23095, https://doi.org/10.1029/2001jd000807, 2001.

Blake, N. J., Blake, D. R., Simpson, I. J., Meinardi, S., Swanson, A. L., Lopez, J. P., Katzenstein, A. S., Barletta, B., Shirai, T., Atlas, E., Sachse, G., Avery, M., Vay, S., Fuelberg, H. E., Kiley, C. M., Kita, K., and Rowland, F. S.: NMHCs and halocarbons in Asian continental outflow during the Transport and Chemical Evolution over the Pacific (TRACE-P) Field Campaign: Com- 
parison with PEM-West B, J. Geophys. Res.-Atmos., 108, 8806, https://doi.org/10.1029/2002jd003367, 2003.

Browell, E. V., Fenn, M. A., Butler, C. F., Grant, W. B., Brackett, V. G., Hair, J. W., Avery, M. A., Newell, R. E., Hu, Y. L., Fuelberg, H. E., Jacob, D. J., Anderson, B. E., Atlas, E. L., Blake, D. R., Brune, W. H., Dibb, J. E., Fried, A., Heikes, B. G., Sachse, G. W., Sandholm, S. T., Singh, H. B., Talbot, R. W., Vay, S. A., Weber, R. J., and Bartlett, K. B.: Large-scale ozone and aerosol distributions, air mass characteristics, and ozone fluxes over the western Pacific Ocean in late winter/early spring, J. Geophys. Res.-Atmos., 108, 8805, https://doi.org/10.1029/2002jd003290, 2003.

Charlton-Perez, C. L., Evans, M. J., Marsham, J. H., and Esler, J. G.: The impact of resolution on ship plume simulations with $\mathrm{NO}_{x}$ chemistry, Atmos. Chem. Phys., 9, 7505-7518, https://doi.org/10.5194/acp-9-7505-2009, 2009.

Ciais, P., Sabine, C., Bala, G., Bopp, L., Brovkin, V., Canadell, J., Chhabra, A., DeFries, R., Galloway, J., Heimann, M., Jones, C., Le Quéré, C., Myneni, R. B., Piao, S., and Thornton, P.: Carbon and Other Biogeochemical Cycles, in: Climate Change 2013: The Physical Science Basis, IPCC WGI Contribution to the Fifth Assessment Report, edited by: Stocker, T. F., Qin, D., Plattner, G.-K., Tignor, M., Allen, S. K., Boschung, J., Nauels, A., Xia, Y., Bex, V., and Midgley, P. M., Cambridge, UK, 46-5-570, 2013.

Collins, W. J., Lamarque, J.-F., Schulz, M., Boucher, O., Eyring, V., Hegglin, M. I., Maycock, A., Myhre, G., Prather, M., Shindell, D., and Smith, S. J.: AerChemMIP: quantifying the effects of chemistry and aerosols in CMIP6, Geosci. Model Dev., 10, 585607, https://doi.org/10.5194/gmd-10-585-2017, 2017.

Crawford, J., Olson, J., Davis, D., Chen, G., Barrick, J., Shetter, R., Lefer, B., Jordan, C., Anderson, B., Clarke, A., Sachse, G., Blake, D., Singh, H., Sandolm, S., Tan, D., Kondo, Y., Avery, M., Flocke, F., Eisele, F., Mauldin, L., Zondlo, M., Brune, W., Harder, H., Martinez, M., Talbot, R., Bandy, A., and Thornton, D.: Clouds and trace gas distributions during TRACE-P, J. Geophys. Res.-Atmos., 108, 8818, https://doi.org/10.1029/2002jd003177, 2003.

Dacre, H. F., Clark, P. A., Martinez-Alvarado, O., Stringer, M. A., and Lavers, D. A.: How Do Atmospheric Rivers Form?, B. Am. Meteorol. Soc., 96, 1243-1255, https://doi.org/10.1175/BamsD-14-00031.1, 2015.

Damoah, R., Spichtinger, N., Forster, C., James, P., Mattis, I., Wandinger, U., Beirle, S., Wagner, T., and Stohl, A.: Around the world in 17 days - hemispheric-scale transport of forest fire smoke from Russia in May 2003, Atmos. Chem. Phys., 4, 13111321, https://doi.org/10.5194/acp-4-1311-2004, 2004.

Davis, D. D., Chen, G., Crawford, J. H., Liu, S., Tan, D., Sandholm, S. T., Jing, P., Cunnold, D. M., DiNunno, B., Browell, E. V., Grant, W. B., Fenn, M. A., Anderson, B. E., Barrick, J. D., Sachse, G. W., Vay, S. A., Hudgins, C. H., Avery, M. A., Lefer, B., Shetter, R. E., Heikes, B. G., Blake, D. R., Blake, N., Kondo, Y., and Oltmans, S.: An assessment of western North Pacific ozone photochemistry based on springtime observations from NASA's PEM-West B (1994) and TRACEP (2001) field studies, J. Geophys. Res.-Atmos., 108, 8829, https://doi.org/10.1029/2002jd003232, 2003.

Donner, L. J., Wyman, B. L., Hemler, R. S., Horowitz, L. W., Ming, Y., Zhao, M., Golaz, J. C., Ginoux, P., Lin, S. J., Schwarzkopf, M. D., Austin, J., Alaka, G., Cooke, W. F., Delworth, T. L., Freiden- reich, S. M., Gordon, C. T., Griffies, S. M., Held, I. M., Hurlin, W. J., Klein, S. A., Knutson, T. R., Langenhorst, A. R., Lee, H. C., Lin, Y. L., Magi, B. I., Malyshev, S. L., Milly, P. C. D., Naik, V., Nath, M. J., Pincus, R., Ploshay, J. J., Ramaswamy, V., Seman, C. J., Shevliakova, E., Sirutis, J. J., Stern, W. F., Stouffer, R. J., Wilson, R. J., Winton, M., Wittenberg, A. T., and Zeng, F. R.: The Dynamical Core, Physical Parameterizations, and Basic Simulation Characteristics of the Atmospheric Component AM3 of the GFDL Global Coupled Model CM3, J. Clim., 24, 34843519, https://doi.org/10.1175/2011jcli3955.1, 2011.

Duncan, B. N., Strahan, S. E., Yoshida, Y., Steenrod, S. D., and Livesey, N.: Model study of the cross-tropopause transport of biomass burning pollution, Atmos. Chem. Phys., 7, 3713-3736, https://doi.org/10.5194/acp-7-3713-2007, 2007.

Eastham, S. D., Weisenstein, D. K., and Barrett, S. R. H.: Development and evaluation of the unified troposphericstratospheric chemistry extension (UCX) for the global chemistry-transport model GEOS-Chem, Atmos. Environ., 89, 52-63, https://doi.org/10.1016/j.atmosenv.2014.02.001, 2014.

Eckstein, J., Ruhnke, R., Zahn, A., Neumaier, M., Kirner, O., and Braesicke, P.: An assessment of the climatological representativeness of IAGOS-CARIBIC trace gas measurements using EMAC model simulations, Atmos. Chem. Phys., 17, 2775-2794, https://doi.org/10.5194/acp-17-2775-2017, 2017.

Ehhalt, D. H., Rohrer, F., Kraus, A. B., Prather, M. J., Blake, D. R., and Rowland, F. S.: On the significance of regional trace gas distributions as derived from aircraft campaigns in PEM-West A and B, J. Geophys. Res.-Atmos., 102, 28333-28351, 1997.

Elguindi, N., Clark, H., Ordonez, C., Thouret, V., Flemming, J., Stein, O., Huijnen, V., Moinat, P., Inness, A., Peuch, V. H., Stohl, A., Turquety, S., Athier, G., Cammas, J. P., and Schultz, M.: Current status of the ability of the GEMS/MACC models to reproduce the tropospheric $\mathrm{CO}$ vertical distribution as measured by MOZAIC, Geosci. Model Dev., 3, 501-518, https://doi.org/10.5194/gmd-3-501-2010, 2010.

Engel, A., Bönisch, H., Brunner, D., Fischer, H., Franke, H., Günther, G., Gurk, C., Hegglin, M., Hoor, P., Königstedt, R., Krebsbach, M., Maser, R., Parchatka, U., Peter, T., Schell, D., Schiller, C., Schmidt, U., Spelten, N., Szabo, T., Weers, U., Wernli, H., Wetter, T., and Wirth, V.: Highly resolved observations of trace gases in the lowermost stratosphere and upper troposphere from the Spurt project: an overview, Atmos. Chem. Phys., 6, 283-301, https://doi.org/10.5194/acp-6-283-2006, 2006.

Esler, J. G.: An integrated approach to mixing sensitivities in tropospheric chemistry: A basis for the parameterization of subgridscale emissions for chemistry transport models, J. Geophys. Res.-Atmos., 108, 4632, https://doi.org/10.1029/2003jd003627, 2003.

Fang, Y. Y., Mauzerall, D. L., Liu, J. F., Fiore, A. M., and Horowitz, L. W.: Impacts of 21 st century climate change on global air pollution-related premature mortality, Climatic Change, 121, 239-253, https://doi.org/10.1007/s10584-013-0847-8, 2013.

Fiore, A. M., Naik, V., Spracklen, D. V., Steiner, A., Unger, N., Prather, M., Bergmann, D., Cameron-Smith, P. J., Cionni, I., Collins, W. J., Dalsoren, S., Eyring, V., Folberth, G. A., Ginoux, P., Horowitz, L. W., Josse, B., Lamarque, J. F., MacKenzie, I. A., Nagashima, T., O'Connor, F. M., Righi, M., Rumbold, S. T., Shindell, D. T., Skeie, R. B., Sudo, K., Szopa, S., Takemura, T., 
and Zeng, G.: Global air quality and climate, Chem. Soc. Rev., 41, 6663-6683, https://doi.org/10.1039/C2cs35095e, 2012.

Fishman, J., Hoell, J. M., Bendura, R. D., McNeil, R. J., and Kirchhoff, V. W. J. H.: NASA GTE TRACE A experiment (September-October 1992), Overview, J. Geophys. Res.-Atmos., 101, 23865-23879, https://doi.org/10.1029/96jd00123, 1996.

Gaudel, A., Clark, H., Thouret, V., Jones, L., Inness, A., Flemming, J., Stein, O., Huijnen, V., Eskes, H., Nedelec, P., and Boulanger, D.: On the use of MOZAIC-IAGOS data to assess the ability of the MACC reanalysis to reproduce the distribution of ozone and CO in the UTLS over Europe, Tellus B, 67, 27955, https://doi.org/10.3402/Tellusb.V67.27955, 2015.

Hardacre, C., Wild, O., and Emberson, L.: An evaluation of ozone dry deposition in global scale chemistry climate models, Atmos. Chem. Phys., 15, 6419-6436, https://doi.org/10.5194/acp15-6419-2015, 2015.

Heald, C. L., Jacob, D. J., Fiore, A. M., Emmons, L. K., Gille, J. C., Deeter, M. N., Warner, J., Edwards, D. P., Crawford, J. H., Hamlin, A. J., Sachse, G. W., Browell, E. V., Avery, M. A., Vay, S. A., Westberg, D. J., Blake, D. R., Singh, H. B., Sandholm, S. T., Talbot, R. W., and Fuelberg, H. E.: Asian outflow and transPacific transport of carbon monoxide and ozone pollution: An integrated satellite, aircraft, and model perspective, J. Geophys. Res.-Atmos., 108, 4804, https://doi.org/10.1029/2003jd003507, 2003.

Hecobian, A., Liu, Z., Hennigan, C. J., Huey, L. G., Jimenez, J. L., Cubison, M. J., Vay, S., Diskin, G. S., Sachse, G. W., Wisthaler, A., Mikoviny, T., Weinheimer, A. J., Liao, J., Knapp, D. J., Wennberg, P. O., Kurten, A., Crounse, J. D., St Clair, J., Wang, Y., and Weber, R. J.: Comparison of chemical characteristics of 495 biomass burning plumes intercepted by the NASA DC- 8 aircraft during the ARCTAS/CARB-2008 field campaign, Atmos. Chem. Phys., 11, 13325-13337, https://doi.org/10.5194/acp-1113325-2011, 2011.

Hoell, J. M., Davis, D. D., Liu, S. C., Newell, R., Shipham, M., Akimoto, H., McNeal, R. J., Bendura, R. J., and Drewry, J. W.: Pacific exploratory Mission-West A (PEM-West A): September-October 1991, J. Geophys. Res.-Atmos., 101, 16411653, https://doi.org/10.1029/95jd00622, 1996.

Hoell, J. M., Davis, D. D., Jacob, D. J., Rodgers, M. O., Newell, R. E., Fuelberg, H. E., McNeal, R. J., Raper, J. L., and Bendura, R. J.: Pacific Exploratory Mission in the tropical Pacific: PEMTropics A, August-September 1996, J. Geophys. Res.-Atmos., 104, 5567-5583, https://doi.org/10.1029/1998jd100074, 1999.

Holmes, C. D., Prather, M. J., Sovde, O. A., and Myhre, G.: Future methane, hydroxyl, and their uncertainties: key climate and emission parameters for future predictions, Atmos. Chem. Phys., 13, 285-302, https://doi.org/10.5194/acp-13-285-2013, 2013.

Holmes, C. D., Prather, M. J., and Vinken, G. C. M.: The climate impact of ship $\mathrm{NO}_{x}$ emissions: an improved estimate accounting for plume chemistry, Atmos. Chem. Phys., 14, 6801-6812, https://doi.org/10.5194/acp-14-6801-2014, 2014.

Hoor, P., Fischer, H., Lange, L., Lelieveld, J., and Brunner, D.: Seasonal variations of a mixing layer in the lowermost stratosphere as identified by the CO-O-3 correlation from in situ measurements, J. Geophys. Res.-Atmos., 107, 4044, https://doi.org/10.1029/2000jd000289, 2002.
Hsu, J. and Prather, M. J.: Stratospheric variability and tropospheric ozone, J. Geophys. Res.-Atmos., 114, D06102, https://doi.org/10.1029/2008jd010942, 2009.

Hsu, J., Prather, M. J., Wild, O., Sundet, J. K., Isaksen, I. S. A., Browell, E. V., Avery, M. A., and Sachse, G. W.: Are the TRACE-P measurements representative of the western Pacific during March 2001?, J. Geophys. Res.-Atmos., 109, D02314, https://doi.org/10.1029/2003jd004002, 2004.

Jacob, D. J. and Winner, D. A.: Effect of climate change on air quality, Atmos. Environ., 43, 51-63, https://doi.org/10.1016/j.atmosenv.2008.09.051, 2009.

Jacob, D. J., Crawford, J. H., Kleb, M. M., Connors, V. S., Bendura, R. J., Raper, J. L., Sachse, G. W., Gille, J. C., Emmons, L., and Heald, C. L.: Transport and Chemical Evolution over the Pacific (TRACE-P) aircraft mission: Design, execution, and first results, J. Geophys. Res.-Atmos., 108, 1-19, https://doi.org/10.1029/2002jd003276, 2003.

Jacob, D. J., Crawford, J. H., Maring, H., Clarke, A. D., Dibb, J. E., Emmons, L. K., Ferrare, R. A., Hostetler, C. A., Russell, P. B., Singh, H. B., Thompson, A. M., Shaw, G. E., McCauley, E., Pederson, J. R., and Fisher, J. A.: The Arctic Research of the Composition of the Troposphere from Aircraft and Satellites (ARCTAS) mission: design, execution, and first results, Atmos. Chem. Phys., 10, 5191-5212, https://doi.org/10.5194/acp10-5191-2010, 2010.

Kiley, C. M., Fuelberg, H. E., Palmer, P. I., Allen, D. J., Carmichael, G. R., Jacob, D. J., Mari, C., Pierce, R. B., Pickering, K. E., Tang, Y. H., Wild, O., Fairlie, T. D., Logan, J. A., Sachse, G. W., Shaack, T. K., and Streets, D. G.: An intercomparison and evaluation of aircraft-derived and simulated CO from seven chemical transport models during the TRACE-P experiment, J. Geophys. Res.-Atmos., 108, 8819, https://doi.org/10.1029/2002jd003089, 2003.

Kley, D., Crutzen, P. J., Smit, H. G. J., Vomel, H., Oltmans, S. J., Grassl, H., and Ramanathan, V.: Observations of near-zero ozone concentrations over the convective Pacific: Effects on air chemistry, Science, 274, 230-233, https://doi.org/10.1126/science.274.5285.230, 1996.

Köppe, M., Hermann, M., Brenninkmeijer, C. A. M., Heintzenberg, J., Schlager, H., Schuck, T., Slemr, F., Sprung, D., van Velthoven, P. F. J., Wiedensohler, A., Zahn, A., and Ziereis, H.: Origin of aerosol particles in the mid-latitude and subtropical upper troposphere and lowermost stratosphere from cluster analysis of CARIBIC data, Atmos. Chem. Phys., 9, 8413-8430, https://doi.org/10.5194/acp-9-8413-2009, 2009.

Kunz, A., Schiller, C., Rohrer, F., Smit, H. G. J., Nedelec, P., and Spelten, N.: Statistical analysis of water vapour and ozone in the UT / LS observed during SPURT and MOZAIC, Atmos. Chem. Phys., 8, 6603-6615, https://doi.org/10.5194/acp-8-6603-2008, 2008.

Lamarque, J. F., Emmons, L. K., Hess, P. G., Kinnison, D. E., Tilmes, S., Vitt, F., Heald, C. L., Holland, E. A., Lauritzen, P. H., Neu, J., Orlando, J. J., Rasch, P. J., and Tyndall, G. K.: CAM-chem: description and evaluation of interactive atmospheric chemistry in the Community Earth System Model, Geosci. Model Dev., 5, 369-411, https://doi.org/10.5194/gmd-5369-2012, 2012.

Lamarque, J. F., Shindell, D. T., Josse, B., Young, P. J., Cionni, I., Eyring, V., Bergmann, D., Cameron-Smith, P., Collins, W. J., Do- 
herty, R., Dalsoren, S., Faluvegi, G., Folberth, G., Ghan, S. J., Horowitz, L. W., Lee, Y. H., MacKenzie, I. A., Nagashima, T., Naik, V., Plummer, D., Righi, M., Rumbold, S. T., Schulz, M., Skeie, R. B., Stevenson, D. S., Strode, S., Sudo, K., Szopa, S., Voulgarakis, A., and Zeng, G.: The Atmospheric Chemistry and Climate Model Intercomparison Project (ACCMIP): overview and description of models, simulations and climate diagnostics, Geosci. Model Dev., 6, 179-206, https://doi.org/10.5194/gmd-6179-2013, 2013.

Larsen, M. L., Briner, C. A., and Boehner, P.: On the Recovery of 3D Spatial Statistics of Particles from 1D Measurements: Implications for Airborne Instruments, J. Atmos. Ocean Tech., 31, 2078-2087, https://doi.org/10.1175/Jtech-D-14-00004.1, 2014.

Lawrence, M. G., Jökel, P., and von Kuhlmann, R.: What does the global mean $\mathrm{OH}$ concentration tell us?, Atmos. Chem. Phys., 1, 37-49, https://doi.org/10.5194/acp-1-37-2001, 2001.

Lelieveld, J. and Crutzen, P. J.: The Role of Clouds in Tropospheric Photochemistry, J. Atmos. Chem., 12, 229-267, https://doi.org/10.1007/Bf00048075, 1991.

Li, J. Y., Mao, J. Q., Min, K. E., Washenfelder, R. A., Brown, S. S., Kaiser, J., Keutsch, F. N., Volkamer, R., Wolfe, G. M., Hanisco, T. F., Pollack, I. B., Ryerson, T. B., Graus, M., Gilman, J. B., Lerner, B. M., Warneke, C., de Gouw, J. A., Middlebrook, A. M., Liao, J., Welti, A., Henderson, B. H., McNeill, V. F., Hall, S. R., Ullmann, K., Donner, L. J., Paulot, F., and Horowitz, L. W.: Observational constraints on glyoxal production from isoprene oxidation and its contribution to organic aerosol over the Southeast United States, J. Geophys. Res.-Atmos., 121, 9849-9861, https://doi.org/10.1002/2016JD025331, 2016.

Manney, G. L., Bird, J. C., Donovan, D. P., Duck, T. J., Whiteway, J. A., Pal, S. R., and Carswell, A. I.: Modeling ozone laminae in ground-based Arctic wintertime observations using trajectory calculations and satellite data, J. Geophys. Res.-Atmos., 103, 5797-5814, https://doi.org/10.1029/97jd03449, 1998.

Mao, J., Ren, X., Brune, W. H., Olson, J. R., Crawford, J. H., Fried, A., Huey, L. G., Cohen, R. C., Heikes, B., Singh, H. B., Blake, D. R., Sachse, G. W., Diskin, G. S., Hall, S. R., and Shetter, R. E.: Airborne measurement of $\mathrm{OH}$ reactivity during INTEX-B, Atmos. Chem. Phys., 9, 163-173, https://doi.org/10.5194/acp-9163-2009, 2009.

Marenco, A., Thouret, V., Nédélec, P., Smit, H., Helten, M., Kley, D., Karcher, F., Simon, P., Law, K., Pyle, J., Poschmann, G., Von Wrede, R., Hume, C., and Cook, T.: Measurement of ozone and water vapor by Airbus in-service aircraft: The MOZAIC airborne program, an overview, J. Geophys. Res.-Atmos., 103, 2563125642, https://doi.org/10.1029/98jd00977, 1998.

Mickley, L. J., Jacob, D. J., Field, B. D., and Rind, D.: Effects of future climate change on regional air pollution episodes in the United States, Geophys. Res. Lett., 31, L24103, https://doi.org/10.1029/2004g1021216, 2004

Mundhenk, B. D., Barnes, E. A., and Maloney, E. D.: AllSeason Climatology and Variability of Atmospheric River Frequencies over the North Pacific, J. Clim., 29, 4885-4903, https://doi.org/10.1175/Jcli-D-15-0655.1, 2016.

Naik, V., Horowitz, L. W., Fiore, A. M., Ginoux, P., Mao, J. Q., Aghedo, A. M., and Levy, H.: Impact of preindustrial to presentday changes in short-lived pollutant emissions on atmospheric composition and climate forcing, J. Geophys. Res.-Atmos., 118, 8086-8110, https://doi.org/10.1002/jgrd.50608, 2013a.
Naik, V., Voulgarakis, A., Fiore, A. M., Horowitz, L. W., Lamarque, J. F., Lin, M., Prather, M. J., Young, P. J., Bergmann, D., Cameron-Smith, P. J., Cionni, I., Collins, W. J., Dalsoren, S. B., Doherty, R., Eyring, V., Faluvegi, G., Folberth, G. A., Josse, B., Lee, Y. H., MacKenzie, I. A., Nagashima, T., van Noije, T. P. C., Plummer, D. A., Righi, M., Rumbold, S. T., Skeie, R., Shindell, D. T., Stevenson, D. S., Strode, S., Sudo, K., Szopa, S., and Zeng, G.: Preindustrial to present-day changes in tropospheric hydroxyl radical and methane lifetime from the Atmospheric Chemistry and Climate Model Intercomparison Project (ACCMIP), Atmos. Chem. Phys., 13, 5277-5298, https://doi.org/10.5194/acp13-5277-2013, 2013b.

Nappo, C. J., Caneill, J. Y., Furman, R. W., Gifford, F. A., Kaimal, J. C., Kramer, M. L., Lockhart, T. J., Pendergast, M. M., Pielke, R. A., Randerson, D., Shreffler, J. H., and Wyngaard, J. C.: The Workshop on the Representativeness of MeteorologicalObservations, June 1981, Boulder, Colorado, B. Am. Meteorol. Soc., 63, 761-764, 1982

Newell, R. E., Newell, N. E., Zhu, Y., and Scott, C.: Tropospheric Rivers - a Pilot-Study, Geophys. Res. Lett., 19, 2401-2404, https://doi.org/10.1029/92g102916, 1992.

Newell, R. E., V, T., Cho, J. Y. N., Stoller, P., Marenco, A., and Smit, H. G.: Ubiquity of quasi-horizontal layers in the troposphere, Nature, 398, 316-319, https://doi.org/10.1038/18642, 1999.

Nicely, J. M., Anderson, D. C., Canty, T. P., Salawitch, R. J., Wolfe, G. M., Apel, E. C., Arnold, S. R., Atlas, E. L., Blake, N. J., Bresch, J. F., Campos, T. L., Dickerson, R. R., Duncan, B., Emmons, L. K., Evans, M. J., Fernandez, R. P., Flemming, J., Hall, S. R., Hanisco, T. F., Honomichl, S. B., Hornbrook, R. S., Huijnen, V., Kaser, L., Kinnison, D. E., Lamarque, J. F., Mao, J. Q., Monks, S. A., Montzka, D. D., Pan, L. L., Riemer, D. D., Saiz-Lopez, A., Steenrod, S. D., Stell, M. H., Tilmes, S., Turquety, S., Ullmann, K., and Weinheimer, A. J.: An observationally constrained evaluation of the oxidative capacity in the tropical western Pacific troposphere, J. Geophys. Res.-Atmos., 121, 7461-7488, https://doi.org/10.1002/2016JD025067, 2016.

Nicely, J. M., Salawitch, R. J., Canty, T., Anderson, D. C., Arnold, S. R., Chipperfield, M. P., Emmons, L. K., Flemming, J., Huijnen, V., Kinnison, D. E., Lamarque, J. F., Mao, J. Q., Monks, S. A., Steenrod, S. D., Tilmes, S., and Turquety, S.: Quantifying the causes of differences in tropospheric $\mathrm{OH}$ within global models, J. Geophys. Res.-Atmos., 122, 1983-2007, https://doi.org/10.1002/2016JD026239, 2017.

Olson, J. R., Crawford, J. H., Chen, G., Fried, A., Evans, M. J., Jordan, C. E., Sandholm, S. T., Davis, D. D., Anderson, B. E., Avery, M. A., Barrick, J. D., Blake, D. R., Brune, W. H., Eisele, F. L., Flocke, F., Harder, H., Jacob, D. J., Kondo, Y., Lefer, B. L., Martinez, M., Mauldin, R. L., Sachse, G. W., Shetter, R. E., Singh, H. B., Talbot, R. W., and Tan, D.: Testing fast photochemical theory during TRACE-P based on measurements of $\mathrm{OH}, \mathrm{HO}_{2}$, and $\mathrm{CH}_{2} \mathrm{O}$, J. Geophys. Res.-Atmos., 109, D15S10, https://doi.org/10.1029/2003jd004278, 2004.

Olson, J. R., Crawford, J. H., Brune, W., Mao, J., Ren, X., Fried, A., Anderson, B., Apel, E., Beaver, M., Blake, D., Chen, G., Crounse, J., Dibb, J., Diskin, G., Hall, S. R., Huey, L. G., Knapp, D., Richter, D., Riemer, D., Clair, J. S., Ullmann, K., Walega, J., Weibring, P., Weinheimer, A., Wennberg, P., and Wisthaler, A.: An analysis of fast photochemistry over high northern latitudes during spring and summer using in-situ observations from 
ARCTAS and TOPSE, Atmos. Chem. Phys., 12, 6799-6825, https://doi.org/10.5194/acp-12-6799-2012, 2012.

Palancar, G. G., Shetter, R. E., Hall, S. R., Toselli, B. M., and Madronich, S.: Ultraviolet actinic flux in clear and cloudy atmospheres: model calculations and aircraftbased measurements, Atmos. Chem. Phys., 11, 5457-5469, https://doi.org/10.5194/acp-11-5457-2011, 2011.

Pan, L., Atlas, E., Salawitch, R., Honomichl, S., Bresch, J., Randel, W., Apel, E., Hornbrook, R., Weinheimer, A., Anderson, D., Andrews, S., Baidar, S., Beaton, S., Carpenter, L. J., Chen, D., Dix, B., Donets, V., Hall, S., Hanisco, T., Homeyer, C., Huey, L., Jensen, J., Kaser, L., Kinnison, D., Koenig, T., Lamarque, J., Liu, C., Luo, J., Luo, Z., Montzka, D., Nicely, J., Pierce, R., Riemer, D., Robinson, T., Romashkin, P., Saiz-Lopez, A., Schauffler, S., Shieh, O., Stell, M., Ullmann, K., Vaughan, G., Volkamer, R., and Wolfe, G.: The Convective Transport of Active Species in the Tropics (CONTRAST) Experimen, B. Am. Meteor. Soc., 106128, https://doi.org/10.1175/BAMS-D-14-00272.1, 2017.

Pan, L. L., Wei, J. C., Kinnison, D. E., Garcia, R. R., Wuebbles, D. J., and Brasseur, G. P.: A set of diagnostics for evaluating chemistry-climate models in the extratropical tropopause region, J. Geophys. Res.-Atmos., 112, D09316, https://doi.org/10.1029/2006jd007792, 2007.

Parrington, M., Palmer, P. I., Lewis, A. C., Lee, J. D., Rickard, A. R., Di Carlo, P., Taylor, J. W., Hopkins, J. R., Punjabi, S., Oram, D. E., Forster, G., Aruffo, E., Moller, S. J., Bauguitte, S. J. B., Allan, J. D., Coe, H., and Leigh, R. J.: Ozone photochemistry in boreal biomass burning plumes, Atmos. Chem. Phys., 13, 73217341, https://doi.org/10.5194/acp-13-7321-2013, 2013.

Paulson, S. E. and Orlando, J. J.: The reactions of ozone with alkenes: An important source of $\mathrm{HO}_{x}$ in the boundary layer, Geophys. Res. Lett., 23, 3727-3730, https://doi.org/10.1029/96g103477, 1996.

PhotoComp: Stratospheric Chemistry SPARC Report No. 5 on the Evaluation of Chemistry, Climate Models, 194-202, 2010.

Pisso, I., Real, E., Law, K. S., Legras, B., Bousserez, N., Attie, J. L., and Schlager, H.: Estimation of mixing in the troposphere from Lagrangian trace gas reconstructions during long-range pollution plume transport, J. Geophys. Res.-Atmos., 114, D19301, https://doi.org/10.1029/2008jd011289, 2009.

Prather, M. and Jaffe, A. H.: Global Impact of the Antarctic Ozone Hole - Chemical Propagation, J. Geophys. Res.-Atmos., 95, 3473-3492, 1990.

Prather, M., Gauss, M., Berntsen, T., Isaksen, I., Sundet, J., Bey, I., Brasseur, G., Dentener, F., Derwent, R., Stevenson, D., Grenfell, L., Hauglustaine, D., Horowitz, L., Jacob, D., Mickley, L., Lawrence, M., von Kuhlmann, R., Muller, J.-F., Pitari, G., Rogers, H., Johnson, M., Pyle, J., Law, K., van Weele, M., and Wild, O.: Fresh air in the 21 st century?, Geophys. Res. Lett., 30, 1100, https://doi.org/10.1029/2002g1016285, 2003.

Prather, M. J.: Time scales in atmospheric chemistry: Theory, GWPs for $\mathrm{CH}_{4}$ and $\mathrm{CO}$, and runaway growth, Geophys. Res. Lett., 23, 2597-2600, 1996.

Prather, M. J.: Tropospheric $\mathrm{O}_{3}$ from photolysis of $\mathrm{O}_{2}$, Geophys. Res. Lett., 36, L03811, https://doi.org/10.1029/2008gl036851, 2009

Prather, M. J.: Photolysis rates in correlated overlapping cloud fields: Cloud-J 7.3c, Geosci. Model Dev., 8, 2587-2595, https://doi.org/10.5194/gmd-8-2587-2015, 2015.
Prather, M. J. and Holmes, C. D.: A perspective on time: loss frequencies, time scales and lifetimes, Environ. Chem., 10, 73-79, https://doi.org/10.1071/En13017, 2013.

Prather, M. J., Holmes, C. D., and Hsu, J.: Reactive greenhouse gas scenarios: Systematic exploration of uncertainties and the role of atmospheric chemistry, Geophys. Res. Lett., 39, L09803, https://doi.org/10.1029/2012gl051440, 2012.

Ramsey, C. A. and Hewitt, A. D.: A methodology for assessing sample representativeness, Environ. Forensics, 6, 71-75, https://doi.org/10.1080/15275920590913877, 2005.

Raper, J. L., Kleb, M. M., Jacob, D. J., Davis, D. D., Newell, R. E., Fuelberg, H. E., Bendura, R. J., Hoell, J. M., and McNeal, R. J.: Pacific Exploratory Mission in the tropical Pacific: PEMTropics B, March-April 1999, J. Geophys. Res.-Atmos., 106, 32401-32425, https://doi.org/10.1029/2000jd900833, 2001.

Reid, S. J., Rex, M., Von der Gathen, P., Floisand, I., Stordal, F., Carver, G. D., Beck, A., Reimer, E., Kruger-Carstensen, R., De Haan, L. L., Braathen, G., Dorokhov, V., Fast, H., Kyro, E., Gil, M., Litynska, Z., Molyneux, M., Murphy, G., O'Connor, F., Ravegnani, F., Varotsos, C., Wenger, J., and Zerefos, C.: A study of ozone laminae using diabatic trajectories, contour advection and photochemical trajectory model simulations, J. Atmos. Chem., 30, 187-207, https://doi.org/10.1023/A:1005836212979, 1998.

Rohrer, F. and Berresheim, H.: Strong correlation between levels of tropospheric hydroxyl radicals and solar ultraviolet radiation, Nature, 442, 184-187, https://doi.org/10.1038/nature04924, 2006.

Schmidt, G. A., Kelley, M., Nazarenko, L., Ruedy, R., Russell, G. L., Aleinov, I., Bauer, M., Bauer, S. E., Bhat, M. K., Bleck, R., Canuto, V., Chen, Y. H., Cheng, Y., Clune, T. L., Del Genio, A., de Fainchtein, R., Faluvegi, G., Hansen, J. E., Healy, R. J., Kiang, N. Y., Koch, D., Lacis, A. A., LeGrande, A. N., Lerner, J., Lo, K. K., Matthews, E. E., Menon, S., Miller, R. L., Oinas, V., Oloso, A. O., Perlwitz, J. P., Puma, M. J., Putman, W. M., Rind, D., Romanou, A., Sato, M., Shindell, D. T., Sun, S., Syed, R. A., Tausnev, N., Tsigaridis, K., Unger, N., Voulgarakis, A., Yao, M. S., and Zhang, J. L.: Configuration and assessment of the GISS ModelE2 contributions to the CMIP5 archive, Journal of Advances in Modeling Earth Systems, 6, 141-184, https://doi.org/10.1002/2013MS000265, 2014.

Schnell, J. L., Prather, M. J., Josse, B., Naik, V., Horowitz, L. W., Cameron-Smith, P., Bergmann, D., Zeng, G., Plummer, D. A., Sudo, K., Nagashima, T., Shindell, D. T., Faluvegi, G., and Strode, S. A.: Use of North American and European air quality networks to evaluate global chemistry-climate modeling of surface ozone, Atmos. Chem. Phys., 15, 10581-10596, https://doi.org/10.5194/acp-15-10581-2015, 2015.

Schoeberl, M. R., Ziemke, J. R., Bojkov, B., Livesey, N., Duncan, B., Strahan, S., Froidevaux, L., Kulawik, S., Bhartia, P. K., Chandra, S., Levelt, P. F., Witte, J. C., Thompson, A. M., Cuevas, E., Redondas, A., Tarasick, D. W., Davies, J., Bodeker, G., Hansen, G., Johnson, B. J., Oltmans, S. J., Vomel, H., Allaart, M., Kelder, H., Newchurch, M., Godin-Beekmann, S., Ancellet, G., Claude, H., Andersen, S. B., Kyro, E., Parrondos, M., Yela, M., Zablocki, G., Moore, D., Dier, H., von der Gathen, P., Viatte, P., Stubi, R., Calpini, B., Skrivankova, P., Dorokhov, V., de Backer, H., Schmidlin, F. J., Coetzee, G., Fujiwara, M., Thouret, V., Posny, F., Morris, G., Merrill, J., Leong, C. P., Koenig-Langlo, G., and 
Joseph, E.: A trajectory-based estimate of the tropospheric ozone column using the residual method, J. Geophys. Res.-Atmos., 112, D24S49, https://doi.org/10.1029/2007jd008773, 2007.

Shindell, D. T., Pechony, O., Voulgarakis, A., Faluvegi, G., Nazarenko, L., Lamarque, J. F., Bowman, K., Milly, G., Kovari, B., Ruedy, R., and Schmidt, G. A.: Interactive ozone and methane chemistry in GISS-E2 historical and future climate simulations, Atmos. Chem. Phys., 13, 2653-2689, https://doi.org/10.5194/acp-13-2653-2013, 2013.

Singh, H. B., Gregory, G. L., Anderson, B., Browell, E., Sachse, G. W., Davis, D. D., Crawford, J., Bradshaw, J. D., Talbot, R., Blake, D. R., Thornton, D., Newell, R., and Merrill, J.: Low ozone in the marine boundary payer of the tropical Pacific Ocean: Photochemical loss, chlorine atoms, and entrainment, J. Geophys. Res.-Atmos., 101, 1907-1917, https://doi.org/10.1029/95jd01028, 1996.

Singh, H. B., Viezee, W., Chen, Y., Bradshaw, J., Sandholm, S., Blake, D., Blake, N., Heikes, B., Snow, J., Talbot, R., Browell, E., Gregory, G., Sachse, G., and Vay, S.: Biomass burning influences on the composition of the remote South Pacific troposphere: analysis based on observations from PEM-Tropics-A, Atmos. Environ., 34, 635-644, https://doi.org/10.1016/S13522310(99)00380-5, 2000.

Sinha, V., Williams, J., Crowley, J. N., and Lelieveld, J.: The Comparative Reactivity Method - a new tool to measure total $\mathrm{OH}$ Reactivity in ambient air, Atmos. Chem. Phys., 8, 2213-2227, https://doi.org/10.5194/acp-8-2213-2008, 2008.

Sovde, O. A., Prather, M. J., Isaksen, I. S. A., Berntsen, T. K., Stordal, F., Zhu, X., Holmes, C. D., and Hsu, J.: The chemical transport model Oslo CTM3, Geosci. Model Dev., 5, 1441-1469, https://doi.org/10.5194/gmd-5-1441-2012, 2012.

Spivakovsky, C. M., Logan, J. A., Montzka, S. A., Balkanski, Y. J., Foreman-Fowler, M., Jones, D. B. A., Horowitz, L. W., Fusco, A. C., Brenninkmeijer, C. A. M., Prather, M. J., Wofsy, S. C., and McElroy, M. B.: Three-dimensional climatological distribution of tropospheric OH: Update and evaluation, J. Geophys. Res.Atmos., 105, 8931-8980, 2000.

Stevenson, D. S., Dentener, F. J., Schultz, M. G., Ellingsen, K., van Noije, T. P. C., Wild, O., Zeng, G., Amann, M., Atherton, C. S., Bell, N., Bergmann, D. J., Bey, I., Butler, T., Cofala, J., Collins, W. J., Derwent, R. G., Doherty, R. M., Drevet, J., Eskes, H. J., Fiore, A. M., Gauss, M., Hauglustaine, D. A., Horowitz, L. W., Isaksen, I. S. A., Krol, M. C., Lamarque, J. F., Lawrence, M. G., Montanaro, V., Muller, J. F., Pitari, G., Prather, M. J., Pyle, J. A., Rast, S., Rodriguez, J. M., Sanderson, M. G., Savage, N. H., Shindell, D. T., Strahan, S. E., Sudo, K., and Szopa, S.: Multimodel ensemble simulations of present-day and near-future tropospheric ozone, J. Geophys. Res.-Atmos., 111, D08301, https://doi.org/10.1029/2005jd006338, 2006.

Stevenson, D. S., Young, P. J., Naik, V., Lamarque, J. F., Shindell, D. T., Voulgarakis, A., Skeie, R. B., Dalsoren, S. B., Myhre, G., Berntsen, T. K., Folberth, G. A., Rumbold, S. T., Collins, W. J., MacKenzie, I. A., Doherty, R. M., Zeng, G., van Noije, T. P. C., Strunk, A., Bergmann, D., Cameron-Smith, P., Plummer, D. A., Strode, S. A., Horowitz, L., Lee, Y. H., Szopa, S., Sudo, K., Nagashima, T., Josse, B., Cionni, I., Righi, M., Eyring, V., Conley, A., Bowman, K. W., Wild, O., and Archibald, A.: Tropospheric ozone changes, radiative forcing and attribution to emissions in the Atmospheric Chemistry and Climate Model Intercompari- son Project (ACCMIP), Atmos. Chem. Phys., 13, 3063-3085, https://doi.org/10.5194/acp-13-3063-2013, 2013.

Stoller, P., Cho, J. Y. N., Newell, R. E., Thouret, V., Zhu, Y., Carroll, M. A., Albercook, G. M., Anderson, B. E., Barrick, J. D. W., Browell, E. V., Gregory, G. L., Sachse, G. W., Vay, S., Bradshaw, J. D., and Sandholm, S.: Measurements of atmospheric layers from the NASA DC- 8 and P-3B aircraft during PEM-Tropics A, J. Geophys. Res.-Atmos., 104, 5745-5764, https://doi.org/10.1029/98jd02717, 1999.

Stone, D., Whalley, L. K., and Heard, D. E.: Tropospheric $\mathrm{OH}$ and $\mathrm{HO}_{2}$ radicals: field measurements and model comparisons, Chem. Soc. Rev., 41, 6348-6404, https://doi.org/10.1039/c2cs35140d, 2012.

Strahan, S. E., Duncan, B. N., and Hoor, P.: Observationally derived transport diagnostics for the lowermost stratosphere and their application to the GMI chemistry and transport model, Atmos. Chem. Phys., 7, 2435-2445, https://doi.org/10.5194/acp-72435-2007, 2007.

Thuburn, J. and Tan, D. G. H.: A parameterization of mixdown time for atmospheric chemicals, J. Geophys. Res.-Atmos., 102 13037-13049, https://doi.org/10.1029/97jd00408, 1997.

Tilmes, S., Lamarque, J. F., Emmons, L. K., Kinnison, D. E., Marsh, D., Garcia, R. R., Smith, A. K., Neely, R. R., Conley, A., Vitt, F., Martin, M. V., Tanimoto, H., Simpson, I., Blake, D. R., and Blake, N.: Representation of the Community Earth System Model (CESM1) CAM4-chem within the ChemistryClimate Model Initiative (CCMI), Geosci. Model Dev., 9, 18531890, https://doi.org/10.5194/gmd-9-1853-2016, 2016.

Turner, A. J., Fiore, A. M., Horowitz, L. W., and Bauer, M.: Summertime cyclones over the Great Lakes Storm Track from 18602100: variability, trends, and association with ozone pollution, Atmos. Chem. Phys., 13, 565-578, https://doi.org/10.5194/acp13-565-2013, 2013

Wild, O., Sundet, J. K., Prather, M. J., Isaksen, I. S. A., Akimoto, H., Browell, E. V., and Oltmans, S. J.: Chemical transport model ozone simulations for spring 2001 over the western Pacific: Comparisons with TRACE-P lidar, ozonesondes, and Total Ozone Mapping Spectrometer columns, J. Geophys. Res.-Atmos., 108, 8826, https://doi.org/10.1029/2002jd003283, 2003.

Wofsy, S. C., Team, H. S., Team, C. M., and Team, S.: HIAPER Pole-to-Pole Observations (HIPPO): fine-grained, globalscale measurements of climatically important atmospheric gases and aerosols, Philos. T. R. Soc. A, 369, 2073-2086, https://doi.org/10.1098/rsta.2010.0313, 2011.

Wu, S. L., Mickley, L. J., Jacob, D. J., Logan, J. A., Yantosca, R. M., and Rind, D.: Why are there large differences between models in global budgets of tropospheric ozone?, J. Geophys. Res.-Atmos., 112, D05302, https://doi.org/10.1029/2006jd007801, 2007.

Young, P. J., Archibald, A. T., Bowman, K. W., Lamarque, J. F., Naik, V., Stevenson, D. S., Tilmes, S., Voulgarakis, A., Wild, O., Bergmann, D., Cameron-Smith, P., Cionni, I., Collins, W. J., Dalsoren, S. B., Doherty, R. M., Eyring, V., Faluvegi, G., Horowitz, L. W., Josse, B., Lee, Y. H., MacKenzie, I. A., Nagashima, T., Plummer, D. A., Righi, M., Rumbold, S. T., Skeie, R. B., Shindell, D. T., Strode, S. A., Sudo, K., Szopa, S., and Zeng, G.: Preindustrial to end 21 st century projections of tropospheric ozone from the Atmospheric Chemistry and Climate Model Intercomparison Project (ACCMIP), Atmos. Chem. Phys., 13, 20632090, https://doi.org/10.5194/acp-13-2063-2013, 2013. 